\title{
Individual and combined effect of TP53, MDM2, MDM4, MTHFR, CCR5, and CASP8 gene polymorphisms in lung cancer
}

\author{
Ausra Stumbryte ${ }^{1,2}{ }$ Zivile Gudleviciene $^{1}$, Gabrielis Kundrotas $^{1}$, Daiva Dabkeviciene ${ }^{2}$, \\ Agne Kunickaite $^{3}$ and Saulius Cicenas ${ }^{4,5}$ \\ ${ }^{1}$ Biobank, National Cancer Institute, LT-08660 Vilnius, Lithuania \\ ${ }^{2}$ Institute of Biosciences, Vilnius University Life Sciences Center, LT-10257 Vilnius, Lithuania \\ ${ }^{3}$ Department of Human and Medical Genetics, Faculty of Medicine, Vilnius University, LT-08661 Vilnius, Lithuania \\ ${ }^{4}$ Department of Thoracic Surgery and Oncology, National Cancer Institute, LT-08660 Vilnius, Lithuania \\ ${ }^{5}$ Faculty of Medicine, Vilnius University, LT-03101 Vilnius, Lithuania \\ Correspondence to: Ausra Stumbryte, email: ausra.stumbryte@nvi.It
}

Keywords: lung cancer prognostic markers; SNPS; patient survival; mortality rate; HPV phylogenetic line

Received: March 22, $2017 \quad$ Accepted: November 01, $2017 \quad$ Published: November 29, 2017

Copyright: Stumbryte et al. This is an open-access article distributed under the terms of the Creative Commons Attribution License 3.0 (CC BY 3.0), which permits unrestricted use, distribution, and reproduction in any medium, provided the original author and source are credited.

\section{ABSTRACT}

Lung cancer (LC) is the second common and with the highest mortality oncological disease. Specific biomarkers for its diagnostics, treatment, and prognosis are still under the investigations. Aim of our study was to evaluate the relationship between the polymorphisms of TP53 pathway genes TP53, MDM2, MDM4, the polymorphisms of HPV-associated genes MTHFR, CASP8, CCR5, and HPV infection with survival of LC patients. SNPs were genotyped using PCR-RFLP. qRT-PCR was used to detect, identify, and quantify HPV. No statistically significant differences were detected between individual SNPs and patient survival with stage I-IV LC. Cluster analysis of SNPs in genes MDM4 A/A, CCR5 wt/ $\triangle 32$, MTHFR C/T, MDM2 T/T showed possible association with the worse survival. Patients who were diagnosed with $C / T$ polymorphic variant of gene MTHFR tend not to survive stage III-IV LC $(P=.12)$. There is a tendency between MDM2 gene T/T variant and worse survival of patients diagnosed with late stage LC $(P=.11)$. HPV infection is very rear among LC patients ( 3 of 92$)$. Overall, there is a link, although statistically insignificant, between specific SNPs and LC patient survival frequency and time, meanwhile the combination of specific SNPs showed a statistically significant measure. In conclusion, we determined statistically significant $(P=.04)$ link between the poor survival of LC patients after surgery and the combination of polymorphic variants $\mathrm{C} / \mathrm{T}$ of the MTHFR and T/T of the MDM2 genes, whereas individually these SNPs do not show significant relationship with the survival of patients after surgery.

\section{INTRODUCTION}

Lung cancer (LC) is one of the most common malignant tumors [1] and the leading cause of all cancer related deaths worldwide [2]. It is characterized by uncontrolled growth of cells comprising pulmonary tissue, which causes a significant decline in human health and life expectancy [1]. According to the World Health Organization, about 1.8 million people (1.240.600 men and 583.100 women) all over the world were newly diagnosed with LC in 2012, which represents $12.7 \%$ of all new cancer cases that year. During the same year LC resulted in death at least 1.59 million times $(1.098 .700$ male and 491.200 female) globally, which is $18.2 \%$ of all deaths caused by cancer per annum $[2,3]$. Epidemiological data on LC in Lithuania reflects similar tendencies with 1421 new cases ( $8 \%$ of all cancers) and 1355 deaths $(16.97 \%)$ in 2012 [4].

There are two main pathological types of LC: smallcell lung cancer (SCLC) and non-small-cell lung cancer 
(NSCLC). NSCLC is the most common form of LC, where about $85 \%$ of cancers are classified as NSCLC, while SCLC occurs in approximately $13-15 \%$ of patients [2]. The main symptoms of this disease are coughing, fatigue, dyspnea, and hemoptysis. These symptoms hinder diagnosis, since patients usually have a confused idea of the causes, therefore the early stages of the disease (stages I and II) are hardly ever detected $[2,5]$. Due to these reasons, most of LC patients usually are diagnosed with an advanced stage (III-IV) and non-resectable disease [6]. About $40 \%$ of patients are diagnosed with LC in stage IV of the disease, and approximately $30 \%$ in stage III. The fact that the disease is diagnosed in its advanced stages reduces the patient's survival rate (5 years) to $16 \%[2,7]$.

It is well known that tobacco is considered to be the main risk factor for LC development. The length of time spent smoking and type of tobacco used may increase the relative risk of acquiring this disease $[2,8$, 9]. Although smoking is the major etiologic factor, not all smokers develop LC. Moreover, approximately $15-25 \%$ of those with LC have never been smokers. Studies of genes candidates and genome-wide association studies have revealed many dysfunctional genes that might be associated with this type of cancer indicating that LC is caused by both genetic and environmental factors, and their interactions as well $[1,10,11]$. Although exposure to carcinogens is considered to be the main cause, there are the new data on Human Papillomavirus (HPV) infection and LC: individual genetic variation and interaction with HPV may contribute to lung cancer development [12].

However, not only tobacco smoking or various infections are responsible for LC development. Various genes and their mutations are closely associated with LC. Large studies were performed to find the exact biomarkers for precise diagnostic and treatment or follow-up of LC patients. On the other hand, multiple biologically relevant polymorphisms may have more accurate prediction power of cancer prognosis compared with single polymorphism because of the modest effect [13]. The functional polymorphisms in genes TP53 (rs1042522), MDM2 (rs2279744), MDM4 (rs4245739), MTHFR (rs1801133), CASP8 (rs3834129), and CCR5 (rs333) alone or in combination, could affect survival in advanced non-small cell lung cancer (NSCLC) patients [13] (Figure 1).

Combined effect of HPV infection and gene polymorphism could have an important role in the development of NSCLC. Recently, it has been reported that high-risk HPV 16/18 3E6 protein is associated with p53 protein degradation in LC [14]. The tumor suppressor TP53 pathway plays a crucial role in preventing carcinogenesis through its ability to impose cell cycle arrest and apoptosis following DNA damage and oncogene activation $[15,16]$. The HPV oncogenic protein E6 has a strong binding affinity for $\mathrm{p} 53$ leading to its ubiquitination and degradation, resulting in reduced protein function and loss of cell cycle control [17]. Multiple functional single nucleotide polymorphysms (SNPs) occur in the TP53 gene and the most frequently studied is the $\mathrm{G}$ to $\mathrm{C}$ change at codon 72 in exon 4, resulting in the amino acid substitution of Arg to Pro (Arg72Pro, rs 1042522). This SNP has been shown to alter TP53 function because it is located in the proline-rich region that is required for TP53 to induce apoptosis. Emerging evidence has shown that the TP53 Arg/Pro polymorphism is not only associated with LC development, but also affects individual sensitivity to platinum-drug chemotherapy and patients' survival [13]. A tendency for a worse prognosis is seen in patients with the Pro/Pro and Arg/Arg genotypes than in those with the Arg/ Pro genotype [3,5]. Recently, in vitro and in vivo studies have indicated a greater susceptibility to degradation by HPV E6 for the p53 protein produced by the Arg allele at codon 72 than for the $\mathrm{p} 53$ protein produced by the Pro allele [7].

In most, if not all, cancers lacking mutation, wildtype 553 is inactivated by interaction with cellular (MDM2/ MDM4) or viral proteins, leading to its degradation [18]. The murine double minute 2 gene (MDM2) is a key negative regulator of the TP53 pathway and usually is overexpressed in many cancers as oncoprotein. MDM2 oncogenic protein is the principal cellular antagonist of the TP53 gene product [19]. DNA damage signals phosphorylation of MDM2 to cause protein structure changes that stabilize p53 resulting in progression through the cell cycle. Moreover, mechanistically MDM2 interacts with HPV E2 protein to synergistically activate the HPV16 promoter, demonstrating E2 can actively recruit MDM2 to the HPV promoter and supporting a role for MDM2 in the transcriptional activity of HPV [17]. A MDM2 SNP at the 309th nucleotide in the first intron (rs2279744), with a $T$ to $G$ change, could increase the affinity for stimulatory protein 1 binding and result in increased MDM2 expression and subsequent attenuation of the TP53 pathway. This polymorphism has been associated with several cancers including LC [20].

The MDM4 protein plays an important role in the negative regulation of the TP53 through its interaction with MDM2. MDM4 amplification has been observed in several tumor forms. A polymorphism (rs4245739 A>C; SNP34091) in the MDM4 3' untranslated region has been reported to create a target site for $h s a-m i R-191$, resulting in decreased MDM4 mRNA levels [21]. Therefore, MDM4, together with TP53, MDM2 and HPV E6 oncoprotein, may play a critical role in HPV-associated carcinogenesis $[17,22]$ and lung cancer as well.

Folate is essential for the synthesis of nucleotides, its deficiency induces double-strand breaks and increases cancer risk [23]. Methylene tetrahydrofolate reductase (encoded by MTHFR) is a key enzyme in metabolism of folate and nucleotides to maintain DNA stability and prevent cancers through catalysing irreversible conversion of 5,10-methylenetetrahydrofolate (5,10-methyleneTHF) to 5-methyl tetrahydrofolate (5-methyl THF) [24, 25, 
26]. The MTHFR gene is located on the short arm of chromosome 1 (1p36.3) and its cDNA has a total length of $2.2 \mathrm{~kb}$ [27]. MTHFR is involved in DNA methylation and synthesis as an important enzyme in the folic acid metabolic process [28]. The most common mutation is a $\mathrm{C}$ to $\mathrm{T}$ transition at nucleotide 677 ( $\mathrm{rs} 1801133, \mathrm{C} 677 \mathrm{~T})$ in exon 4 , resulting in a substitution of alanine with valine [29]. The MTHFR T/T genotype exhibited a significantly increased risk of LC compared to the MTHFR $\mathrm{C} / \mathrm{C}$ and $\mathrm{C} / \mathrm{T}$ genotype [28].

Caspase- 8 (encoded by the CASP 8 gene) is crucial in generating cell death signals and eliminating potentially malignant cells. Genetic variation in CASP 8 may affect susceptibility to cancer [30, 31]. Caspase- 8 is a member of the caspase cysteine protease family and plays an important role in cancer development [32]. $C A S P$ causes cell death by nuclear membrane breakdown, DNA fragmentation, chromatin condensation, and the formation of apoptotic genetic polymorphisms for genes controlling the cell cycle or apoptosis $[1,33]$. Recently, a large number of SNPs in the CASP apoptotic pathway have been increasingly recognized. Several studies have demonstrated that some variants in apoptosis pathway genes are associated with the susceptibility to various human cancers, especially LC $[1,34]$. The CASP $8-652$ $6 \mathrm{~N}$ ins/del (rs3834129) polymorphism has been previously reported to influence the progression to several cancers. Finally, this suggests that the del allele, carrier and ins/ del genotype of the $-6526 \mathrm{~N}$ ins/del polymorphism in the CASP 8 gene may be protective factors for cancer development [30].

Chemokines are a family of small cytokines that regulate leukocytes in tissues, thus playing an important role in regulation of immunological processes [35]. Chemokines participate in many pathophysiological conditions, including malignant tumors progression and metastasis. Role of these substances in malignancies are complex. In addition to their chemotactic properties, chemokines and their receptors also play a part in other biological functions relevant to oncogenesis or they indirectly affect tumor development by attracting immunocompetent cells with pro- or anti-tumoral activities [36]. The CCR5- $\triangle 32$ polymorphism (rs333), which is a 32-bp deletion in the coding region, encodes a truncated inactive receptor that is not expressed on the cell membrane. Moreover, molecular epidemiological studies showed that $\Delta 32$ polymorphisms are associated with cancer development [37].

HPVs are small non-enveloped DNA viruses that usually infect squamous epithelial cells [38]. It is well known that HPV is a major risk factor for cervical, anal, vaginal, skin or laryngeal cancers. According to the previous investigations, HPV infection is local and develops only in epithelium. However, there are new data on findings of HPV in breast, prostate, and lung cancers $[39,40]$. These findings paved the way to the idea on HPV transmission through blood or lymph. Another hypothesis states that the virus enters through an oral cavity and spreads among its cells to the lung [2]. While investigating the presence of HPV in the exhaled breath condensate of LC patients [2, 40], high risk types of HPV were found. These findings also suggest a possibility of air stream transmission of HPV. For a long time, it was believed that papillomavirus could not migrate to the other parts of the body through the blood because HPV has not a viremic phase during active infection [2]. However, several studies have reported LC-related HPV infection rates that vary between $10 \%$ and $80 \%$, depending on the different methods used or specific geographical regions investigated [38]. After analysis gathered from global research reports, it was found that $22.4 \%$ of the patients with LC could be presented with an HPV infection, suggesting that HPV infection could be one of the important risk factors to the tumorigenesis of NSCLC [38, 41].

Summing up, all these above described genes or SNPs alone or in combination could affect survival of patients with advanced LC. In this study, we for the first time investigated the impact of a set of HPV and such different SNPs as TP53 Arg72Pro (rs1042522), MDM2 T309G (rs2279744), MDM4 (rs4245739), MTHFR (rs1801133), CASP8 (rs3834129), and CCR5 (rs333) on the advanced LC patients`survival.

\section{RESULTS}

\section{Patient characteristics}

The mean age of the patients included in the study was 63 years (SD 8.7). Tumor cases from $76(82.6 \%)$ male and $16(17.4 \%)$ female patients were collected during the surgical operation. Histological type of cancer distribute as follows: 41 squamous-cell carcinoma (45.1\%), 31 adenocarcinoma (34.1\%), 6 pleomorphiccell carcinoma (6.6\%), 5 large-cell carcinoma (5.5\%), 4 small-cell carcinoma (4.4\%), 2 carcinoid (2.2\%), 1 giantcell carcinoma (1.1\%), 1 chorio-carcinoma (1.1\%), one case histology type has not been established. 92 lung cancer patients were divided into groups according to the stage of diagnosis: stage I - 36 (39.1\%), stage II $28(30.4 \%)$, stage III - $23(25.0 \%)$, and stage IV - 5 $(5.4 \%)$. Regarding the smoking status, 16 patients were non-smokers, 75 patients smoked, while in 1 case the data was not given.

\section{Allele and genotype distribution}

In our study we investigated the TP53 Arg72Pro (rs1042522), MDM2 T309G (rs2279744), MDM4 (rs4245739), MTHFR (rs1801133), CASP8 (rs3834129), and CCR5 (rs333) polymorphisms in 92 Lithuanian LC patients. After analysis the TP53 gene Arg72Pro genotype distributions were as follows: the majority of 
sampled patients were identified as Arg/Pro polymorphic variant $(95.7 \%)$ and only in a few samples genotype of Arg/Arg (4.4\%) was found. Pro/Pro polymorphic variant was not detected in our investigated cases. The allele frequencies for MDM2 gene (-410T-G) SNP (T/T, T/G, and $\mathrm{G} / \mathrm{G})$ were $50.0 \%, 43.5 \%$, and $6.5 \%$, respectively. MDM4 gene $\mathrm{A}>\mathrm{C}$ SNP distributions (A/A, A/C, and $\mathrm{C} / \mathrm{C}$ ) were recorded to be $59.8 \%, 32.6 \%$, and $7.6 \%$, respectively. MTHFR gene C677T SNP distribution was as follows: $\mathrm{C} / \mathrm{C} 58.7 \%, \mathrm{C} / \mathrm{T} 36.9 \%$, T/T $4.4 \%$. CASP8 gene (-652 $6 \mathrm{~N}$ ins/del) ins/ins, ins/del, and $\mathrm{del} / \mathrm{del}$ genotype distribution was $28.3 \%, 66.3 \%$, $5.4 \%$, respectively. CCR5 gene-delta32 deletion SNP distribution was: wt/wt 83.7\%, wt/ $\Delta 3214.1 \%, \Delta 32 / \Delta 32$ $2.2 \%$. The frequency distributions of all genotypes among patients are presented in Table 1 .

Subgroup analysis revealed marked relation between MDM2 SNP distribution and patient sex $(\chi 2=$ $5.1, P=.08, \mathrm{df}=2$ ) (Table 1). MDM2c. $-5+309 \mathrm{G}>\mathrm{T} \mathrm{G} / \mathrm{G}$ polymorphic variant was detected in higher frequency (18.8\%) among female patients (3 of 16 patients), while in samples of male patients accounted only for $4.0 \%$ (3 of 76 patients). $\mathrm{T} / \mathrm{T}$ polymorphic variant was detected in $52.6 \%$ of male samples (40 of 70 patients) and in $37.5 \%$ of female samples (6 of 16 patients). MTHFRc.677 C $>\mathrm{T}$ $\mathrm{C} / \mathrm{C}$ polymorphic variant was characterized by the greater frequency $(75.0 \%)$ in women samples (12 patients out of 16), in comparison to $55.3 \%$ of male samples (42 patients out of 76). C/T polymorphic variant was detected more frequently $(40.8 \%)$ in male patients (31 patients out of 76), while in female patients it amounted for $18.7 \%$ ( 3 of 16 female patients). However, all these differences were not statistically significant $\left(\chi^{2}=2.8\right.$, $P=.25, \mathrm{df}=2)$. Survival analysis according to TP53c. 215 $\mathrm{G}>\mathrm{C}$ (Arg72Pro), MDM2c.-5+309 G>T, MDM4c.1q32 A $>$ C, MTHFRc.677 C $>$ T, CASP8c. $-6526 \mathrm{~N}$ ins/del, CCR5c. $-\triangle 32$ genes SNPs

The main task of our study was to determine the relationship between polymorphic variants of genes TP53c.215 G>C (Arg72Pro), MDM2c.-5+309 G>T, MDM4c.1q32 A>C, MTHFRc.677 C>T, CASP8c.-652 6N ins/del, $C C R 5-\triangle 32$ and LC patients' survival. Due to the lack of uncensored values of Arg/Arg and Pro/Pro in SNP case, survival rate curves according to TP53 gene Arg/Pro, Arg/Arg, and Pro/Pro SPNs were not presented. However, it should be noted that $3(75.0 \%)$ LC patients out of 4 diagnosed with Arg/Arg polymophic variant survived until the last day of this study. Meanwhile 51 (57.9\%) patients out of 88 survived until the last day of trial with Arg/Pro polymorphic variant detected.

After identifying polymorphic variants of MDM2c.-5+309 G>T gene in the test group it was found that patients with $\mathrm{T} / \mathrm{G}$ polymorphic variant had a better survival rate over patients with $\mathrm{G} / \mathrm{G}$ and $\mathrm{T} / \mathrm{T}$ variants $P=$.38) (Figure 2A). For patients who were identified with $\mathrm{T} / \mathrm{G}$ polymorphic variant after 1600 days survival rates amounted to $56.9 \%$, and for those who were determined by $\mathrm{T} / \mathrm{T}$ polymorphic variant survival rates reached $48.8 \%$. After approximately 800 days of observation, survival rates of patients with different polymorphic variants were almost identical: $\mathrm{T} / \mathrm{T} 53.5 \%$ and $\mathrm{T} / \mathrm{G} 56.9 \%$. MDM2 gene polymorphic $\mathrm{G} / \mathrm{G}$ variant was identified in only 6 examined samples, therefore they were not included in this survival analysis.

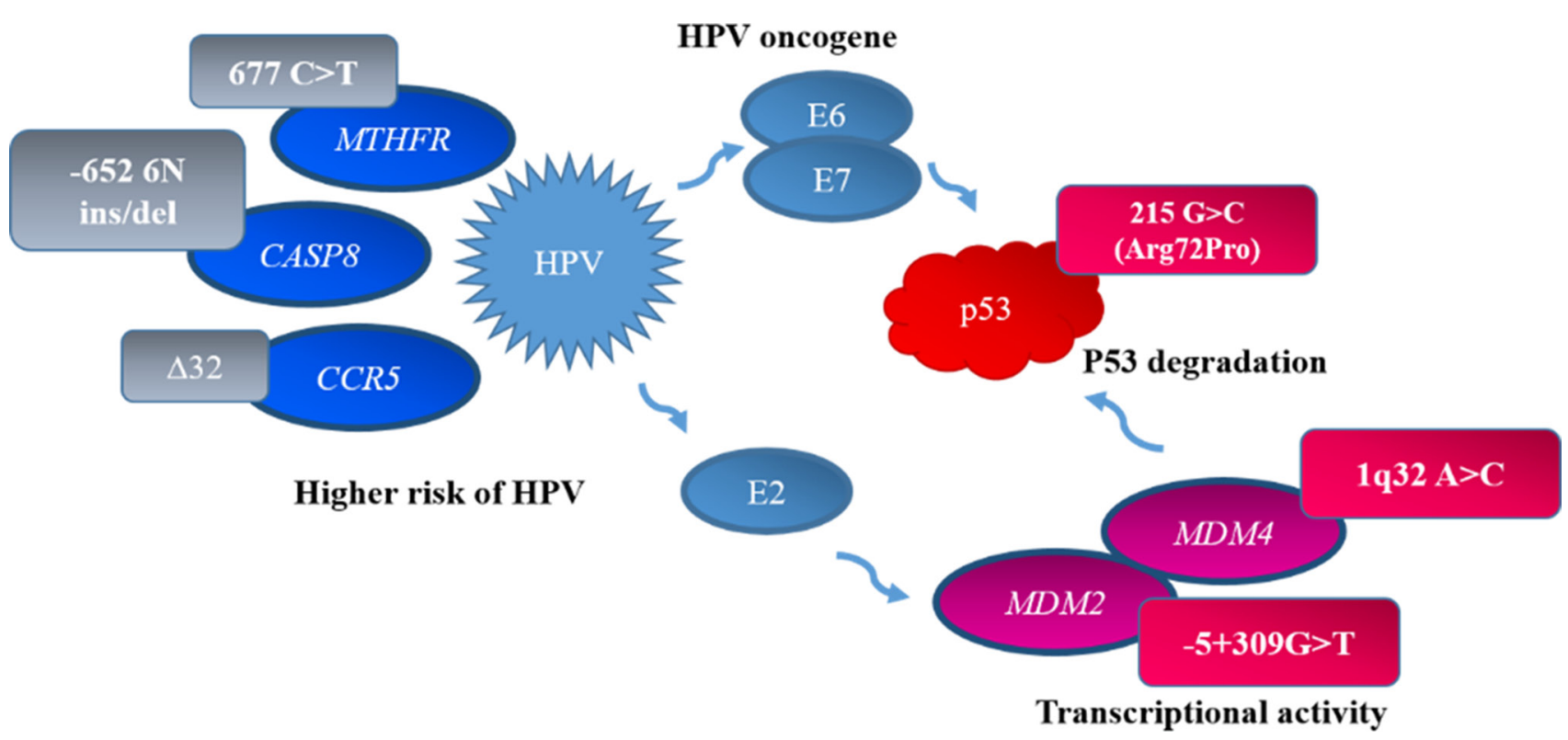

Figure 1: Gene and HPV interactions. p53 is inactivated by HPV E6 protein. This action disturbs cell cycle that generates opportunities for new mutations. HPV E2 protein interacts with MDM2/MDM4 encoded proteins that are concentrated near HPV16 promoter, where these proteins encourage E2 managed transcription activity. Polymorphic variants of genes MTHFR $677 \mathrm{C}>\mathrm{T}$, CASP8-652 6N ins/del, and CCR5 $\triangle 32$ are associated with increased susceptibility to HPV infection. 
Table 1: Genotype and stage frequencies of TP53, MDM2, MDM4, MTHFR, CASP8, CCR5 in lung cancer patients

\begin{tabular}{|c|c|c|c|c|c|c|c|}
\hline \multirow[b]{2}{*}{ Genotype } & \multirow[b]{2}{*}{ No $(\%)$} & \multicolumn{2}{|c|}{ Sex } & \multirow[t]{2}{*}{$P$-value } & \multicolumn{2}{|c|}{ Stage } & \multirow[t]{2}{*}{$P$-value } \\
\hline & & Male $(n=76)$ & Female $(n=16)$ & & I-II & III-IV & \\
\hline (Arg72Pro) & \multicolumn{7}{|c|}{ TP53c.215 G>C } \\
\hline $\begin{array}{l}\text { Arg/Arg } \\
\text { Arg/Pro } \\
\text { Pro/Pro }\end{array}$ & $\begin{array}{c}4(4.3 \%) \\
88(95.7 \%) \\
0(0 \%)\end{array}$ & $\begin{array}{c}3(3.9 \%) \\
73(96.1 \%) \\
0(0 \%)\end{array}$ & $\begin{array}{c}1(6.3 \%) \\
15(93.7 \%) \\
0(0 \%)\end{array}$ & .54 & $\begin{array}{c}2(2.2 \%) \\
61(67.1 \%) \\
0(0 \%)\end{array}$ & $\begin{array}{c}2(2.2 \%) \\
26(28.6 \%) \\
0(0 \%)\end{array}$ & .46 \\
\hline $\begin{array}{c}M D M 2 \mathrm{c} .5+30 \\
\mathrm{~T} / \mathrm{T} \\
\mathrm{T} / \mathrm{G} \\
\mathrm{G} / \mathrm{G}\end{array}$ & $\begin{array}{c}46(50.0 \%) \\
40(43.5 \%) \\
6(6.5 \%)\end{array}$ & $\begin{array}{c}40(52.6 \%) \\
33(43.4 \%) \\
3(4.0 \%)\end{array}$ & $\begin{array}{l}6(37.5 \%) \\
7(43.7 \%) \\
3(18.8 \%)\end{array}$ & .08 & $\begin{array}{c}36(39.6 \%) \\
24(26.4 \%) \\
3(3.3 \%)\end{array}$ & $\begin{array}{c}10(11.0 \%) \\
15(16.5 \%) \\
3(3.3 \%)\end{array}$ & .24 \\
\hline $\begin{array}{c}M D M 4 c .1 q 32 \\
\mathbf{A} / \mathbf{A} \\
\mathbf{A} / \mathbf{C} \\
\mathbf{C} / \mathbf{C}\end{array}$ & $\begin{array}{c}55(59.8 \%) \\
30(32.6 \%) \\
7(7.6 \%)\end{array}$ & $\begin{array}{c}45(59.2 \%) \\
24(31.6 \%) \\
7(9.2 \%)\end{array}$ & $\begin{array}{c}10(62.5 \%) \\
6(37.5 \%) \\
0(0 \%)\end{array}$ & .44 & $\begin{array}{c}37(40.7 \%) \\
21(23.0 \%) \\
5(5.5 \%)\end{array}$ & $\begin{array}{c}17(18.7 \%) \\
9(9.9 \%) \\
2(2.2 \%)\end{array}$ & .45 \\
\hline $\begin{array}{c}\text { MTHFRc.677 } \\
\text { C/C } \\
\text { C/T } \\
\text { T/T }\end{array}$ & $\begin{array}{c}54(58.7 \%) \\
34(36.9 \%) \\
4(4.4 \%)\end{array}$ & $\begin{array}{c}42(55.3 \%) \\
31(40.8 \%) \\
3(3.9 \%)\end{array}$ & $\begin{array}{c}12(75.0 \%) \\
3(18.7 \%) \\
1(6.3 \%)\end{array}$ & .25 & $\begin{array}{c}33(36.3 \%) \\
27(29.7 \%) \\
3(3.3 \%)\end{array}$ & $\begin{array}{c}20(22.0 \%) \\
7(7.7 \%) \\
1(1.1 \%)\end{array}$ & .18 \\
\hline $\begin{array}{r}\text { CASP8c.-652 6N } \\
\text { Ins/ins } \\
\text { Ins/del } \\
\text { Del/del }\end{array}$ & $\begin{array}{c}26(28.3 \%) \\
61(66.3 \%) \\
5(5.4 \%)\end{array}$ & $\begin{array}{c}22(28.9 \%) \\
49(64.5 \%) \\
5(6.6 \%)\end{array}$ & $\begin{array}{c}4(25.0 \%) \\
12(75.0 \%) \\
0(0 \%)\end{array}$ & .51 & $\begin{array}{c}15(16.5 \%) \\
44(48.3 \%) \\
4(4.4 \%)\end{array}$ & $\begin{array}{c}11(12.1 \%) \\
16(17.6 \%) \\
1(1.1 \%)\end{array}$ & .05 \\
\hline $\begin{array}{c}C C R 5-\Delta 3 \\
w t / w t \\
w t / \Delta 32 \\
\Delta 32 / \Delta 32\end{array}$ & $\begin{array}{c}77(83.7 \%) \\
13(14.1 \%) \\
2(2.2 \%)\end{array}$ & $\begin{array}{c}64(84.2 \%) \\
10(13.2 \%) \\
2(2.6 \%)\end{array}$ & $\begin{array}{c}13(81.3 \%) \\
3(18.7 \%) \\
0(0 \%)\end{array}$ & .69 & $\begin{array}{c}55(50.5 \%) \\
7(7,7 \%) \\
1(1.1 \%)\end{array}$ & $\begin{array}{c}21(23.1 \%) \\
6(6.6 \%) \\
1(1.1 \%)\end{array}$ & .74 \\
\hline & \multicolumn{4}{|c|}{ No $=92$} & & No $=91^{*}$ & \\
\hline
\end{tabular}

*For 1 patient the stage has not been evaluated, so this patient is not included in the analysis.

Survival was $55.4 \%$ of patients with $M D M 4 c .1 \mathrm{q} 32$ A $>$ C gene SNP A/A and 48.5\% with SNP A/C at 1600 days post-surgical operation, however, it showed no significant differences in survival groups regarding all tested polymorphic variants $(P=.84)$ (Figure $2 \mathrm{~B})$. C/C polymorphic variant was identified in only 7 examined samples, therefore they were not included in this survival analysis. $\mathrm{C} / \mathrm{T}$ and $\mathrm{C} / \mathrm{C}$ polymorphic variants of the MTHFRc.677 C > T resulted in similar survival rates as the ones observed in the same test group after 1600 days (respectively $47.4 \%$ and $51.0 \%, P=.66$ ) (Figure $2 \mathrm{C}$ ). $\mathrm{T} / \mathrm{T}$ polymorphic variants were identified only in 4 samples. As for CASP8c.-652 $6 \mathrm{~N}$ gene SNP ins/ins survival was 54.2\% and SNP ins/del survival was $54.4 \%$ at 1600 days postsurgical operation $(P=.99)$ (Figure 2D). Del/del allelic variant was identified only in $5 \mathrm{LC}$ samples, therefore the statistical analysis was not performed. Survival differences between CCR5- $\triangle 32$ gene SNP groups were not significant, as SNP wt/ $\triangle 32$ survival was $61.9 \%$ and SNP wt/wt survival was $51.6 \%$ at 1600 days post-surgical operation $(P=.59$ ) (Figure $2 \mathrm{E}$ ). $\Delta 32 / \Delta 32$ polymorphic variant was found in only 2 samples, so statistical analysis was not performed.
Survival analysis according to $M D M 2 c .-5+309$ G>T, MDM4c.1q32 A>C, MTHFRc.677 C > T, CASP8c.-652 6N ins/del, $C C R 5$ - $\Delta 32$ genes SNPs in patients with early and late stages of cancer

Patients who were diagnosed with stage I, II, III, and IV LC had significantly different survival curves $(P<.01)$, and survival rates on 1494 day of study were $72.2 \%, 37.4 \%, 39.2 \%, 20.0 \%$, respectively. Overall, analysis showed that patient survival rates had a trustworthy correlation with the staging of LC. After statistical analysis of tested genes SNPs, no reliable differences were found between patients diagnosed with early (I-II) and late (III-IV) stages of LC (Figure 2). However, after 1418 days survival rates of patients diagnosed with MTHFRc.677 C>T gene SNP C/C and stage I-II LC was $62.7 \%$, while $42.0 \%$ for $\mathrm{C} / \mathrm{T}$ patients $(P=.17)$ (Figure $2 \mathrm{C})$. Patients with stage IIIIV LC who were identified with gene MDM2c.-5 + 309 $\mathrm{G}>\mathrm{T}$ SNPs survival differences were not statistically significant, T/T patients survived post operation up to 

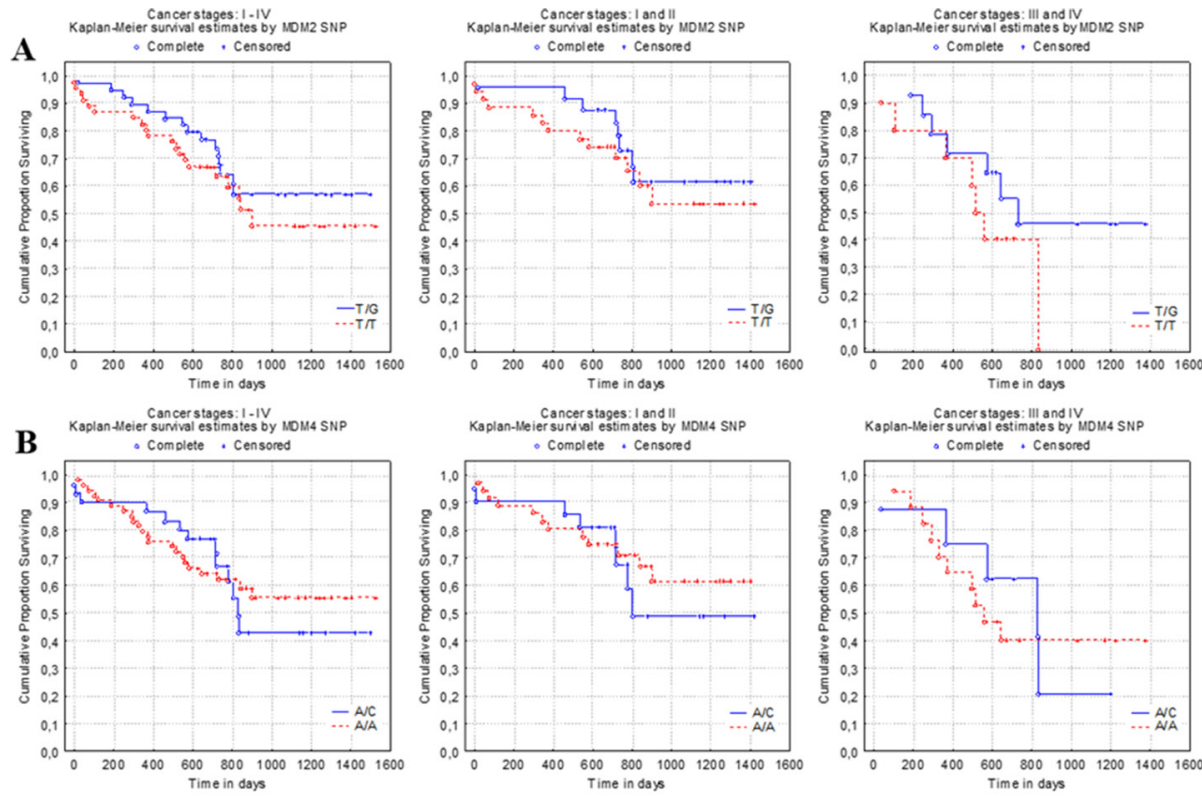

- Complete . Censored

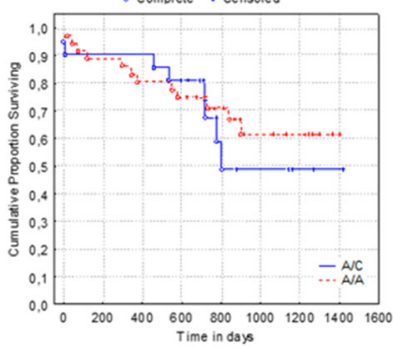

Cancer stages: III and IV
Kaplan-Meier survivi estimates by MOM 4 SNP - Complete . Censored

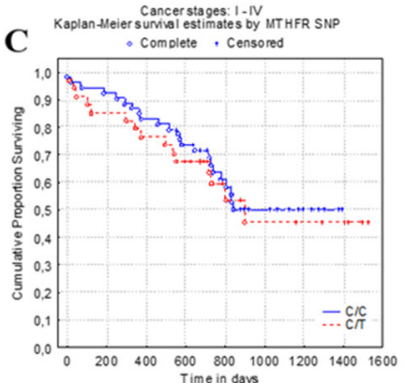

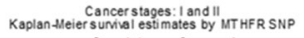
Complete, Censored
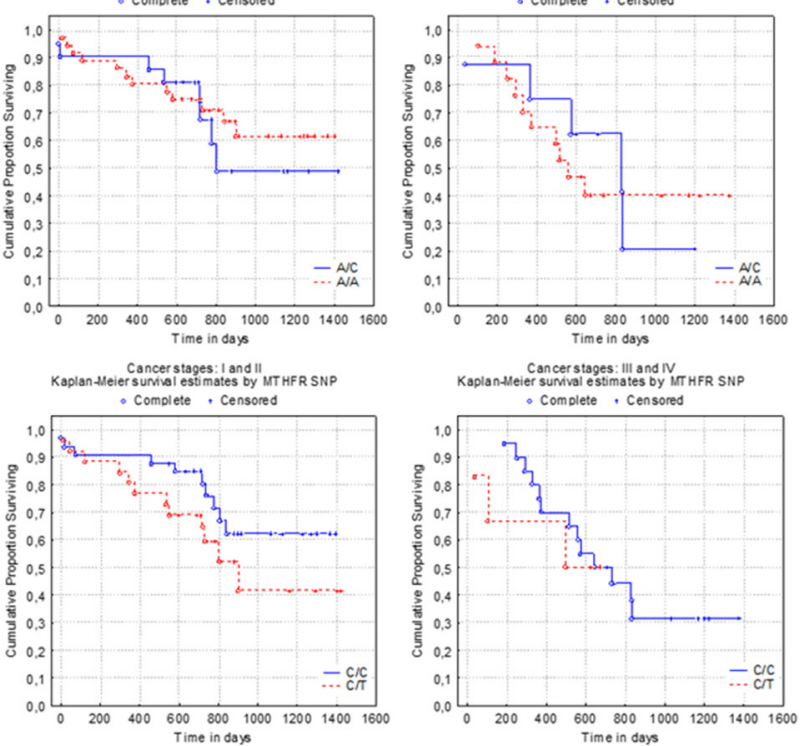

Cancerstages: III and IV
Kaplandieier sumival estimates by IT HFR SNP

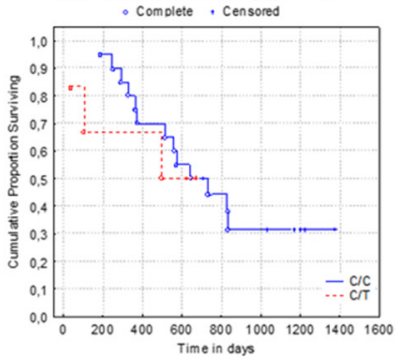

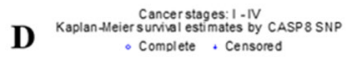

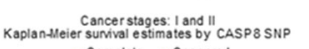
- Complete . Cen sored
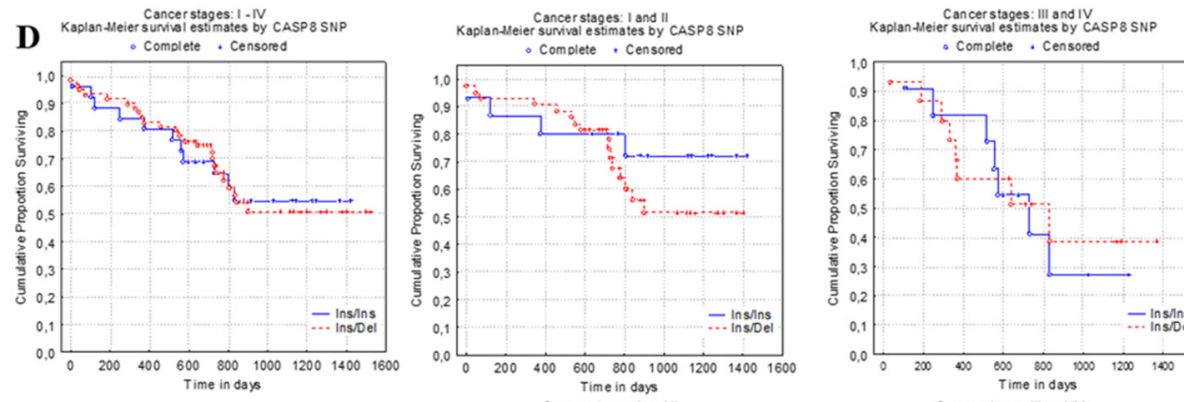

Cancerstages I.IV
E Kaplanntheiers sunisil estimates by CCRS SNP Cancer rtages: I Ind III
Kaplan-Meier suni al estimates by CCR5 SNP
o Complete. Censored
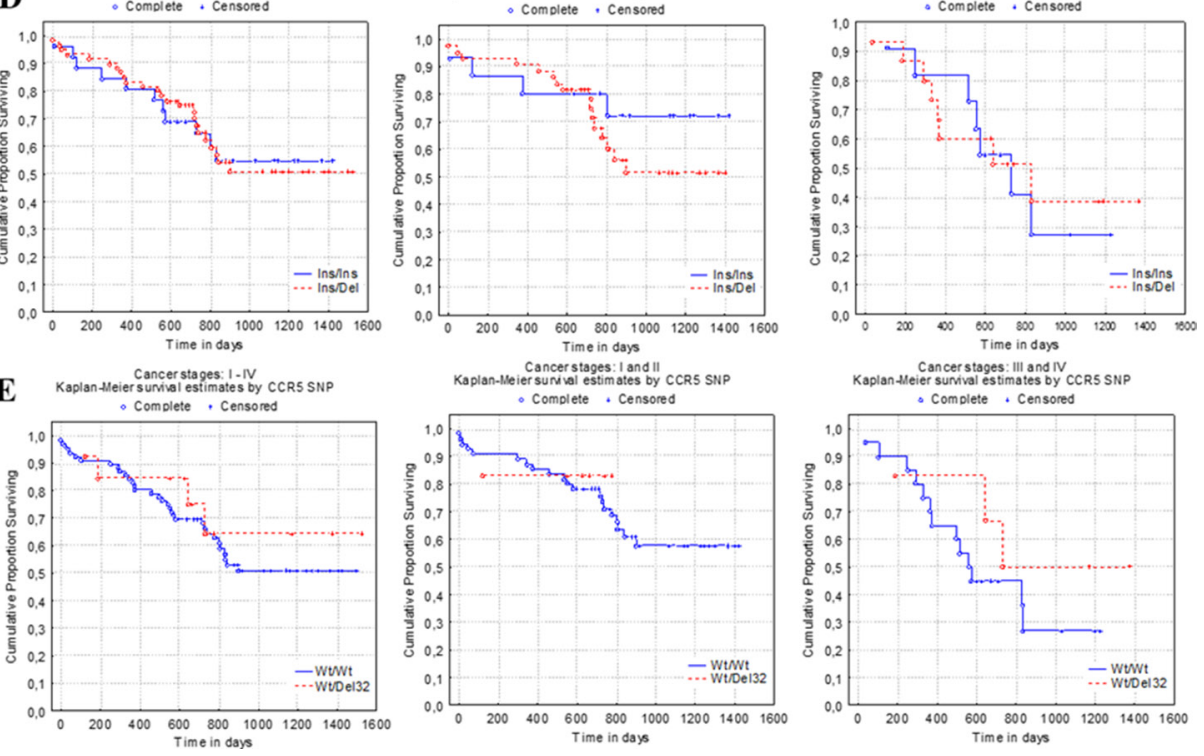

Cancer stages: IIII and IV
Kaplanntheier survival estimates by CCRS SNP - Complete . Censored

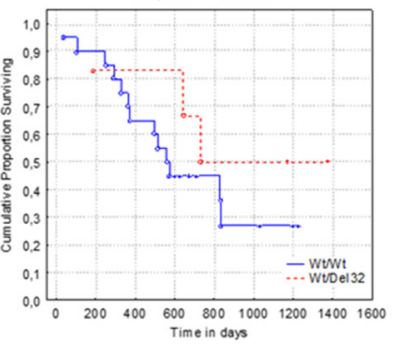

Figure 2: Lung cancer patient survival curves according to MDM2, MDM4, MTHFR, CASP8, and CCR5 genes SNPs. Patients) survival rates: (A) (left) $-M D M 2 \mathrm{c} .-5+309 \mathrm{G}>\mathrm{T}$ gene with T/T and T/G polymorphisms $(P=.383)$; (B) (left) $-M D M 4 \mathrm{c} .1 \mathrm{q} 32 \mathrm{~A}>\mathrm{C}$ gene with $\mathrm{A} / \mathrm{C}, \mathrm{A} / \mathrm{A}$ polymorphisms $(P=.836) ;(\mathbf{C})$ (left) - MTHFRc.677 $\mathrm{C}>\mathrm{T}$ gene polymorphic $\mathrm{C} / \mathrm{T}, \mathrm{C} / \mathrm{C}$ variants $(P=.660) ;($ (D) $(\mathrm{left})$ - CASP8c.-652 6N ins/del gene polymorphic ins/ins, ins/del variants $(P=.986)$; (E) (left) - CCR5- $\triangle 32$ gene wt $/ \Delta 32$, wt/wt polymorphic variants $(P=.593)$. Survival curves of lung cancer patients, who were identified with: A $-M D M 2 \mathrm{c} .5+309 \mathrm{G}>\mathrm{T}$ gene T/G or T/T polymorphic variants at early (centre, $P=.489$ ) and late (right, $P=.227$ ) stages; $\mathrm{B}-M D M 4 \mathrm{c} .1 \mathrm{q} 32 \mathrm{~A}>\mathrm{C}$ gene $\mathrm{A} / \mathrm{C}$ or A/A polymorphic variant at early (centre, $P=.606$ ) and late (right, $P=.866$ ); $\mathrm{C}-M T H F R$ c. $677 \mathrm{C}>\mathrm{T}$ gene $\mathrm{C} / \mathrm{C}, \mathrm{C} / \mathrm{T}$ polymorphic variants at early (centre, $P=.165$ ) and late (right, $P=.728$ ); $\mathrm{D}-C A S P 8 \mathrm{c} .-6526 \mathrm{~N}$ gene ins/del, ins/ins variants at early (centre, $P=.334$ ) and late (right, $P=.793$ ); E - CCR $5-\triangle 32$ gene wt/wt, wt $/ \triangle 32$ variants at early (centre, $P=.760$ ) and late (right, $P=.330$ ) stages. 
800 days, while $43.9 \%$ of $\mathrm{T} / \mathrm{G}$ patients survived until the end of the observation $(P=.23$ ) (Figure 2A). At the end of the study, survival rates were more than $10 \%$ different among the patients diagnosed with stage I-II and identified with SNP of CASP8c.-652 6N gene: $70.6 \%$ in case of ins/ins and $53.0 \%$ in ins/del $(P=.33)$ (Figure 2D). Survival rates of patients diagnosed with III-IV stage of LC and SNPs of CCR $5-\triangle 32$ gene were $26.5 \%$ in case of $w t / w t$ and $46.3 \%$ in wt/ $\Delta 32(P=.33)$ (Figure 2E).

\section{Cluster analysis of TP53, MDM2, MDM4, MTHFR, CASP8, CCR5 genes polymorphic variants}

Finally, cluster analysis was performed on the basis of the patients' mortality rates and survival times to determine which of the analyzed SNPs resulted in the best patient survival. Table 2 and Figure 3 provide the results of cluster analysis. The highest mortality rate had groups of patients who were identified as MDM2 T/T and CCR5 wt/wt (43.4\%), MDM4 A/C and MTHFR C/C (43.3\%) polymorphic variants. The lowest mortality rates were observed in patients who were identified as CCR5 wt/ $\triangle 32$, MDM2 T/G, MTHFR C/T, and CASP8 ins/del genetic polymorphic variants with numerical expressions $30.7 \%$, $38.4 \%, 39.4 \%$, and $40.0 \%$, respectively. For patients who were identified as MDM4 A/A, CASP8 ins/ins, TP53 Arg/ Pro polymorphic variants, mortality rates were $40.7 \%$, $42.3 \%$, and $42.5 \%$, respectively.

It should be emphasized that clasterisation of each SNP mostly depended on survival time median, $Q 1$ and $Q 3$ (represented in Table 2 as interquartile range (IQR)). Cluster analysis identified two patient groups that contained distinct variants of gene polymorphism. In the first group (I) patient survival was up to 437 days and in the second group (II) survival of patients was beyond 437 days. Cluster covering group of patients with better survival rate (II) reveals two more groups: the patients with CASP8 ins/ins, TP53 Arg/Pro gene polymorphism variants (IIA) and with two times longer survival than patients from cluster (I); and the second group (IIB) includes patients with identified MDM4 A/C, CCR5 wt/wt, MTHFR C/C, CASP8 ins/del, MDM2 T/G gene polymorphism variants and their survival was between 498-572 days.

Our cluster analysis showed that the genes in cluster I might be associated with the lowest survival rates. A more

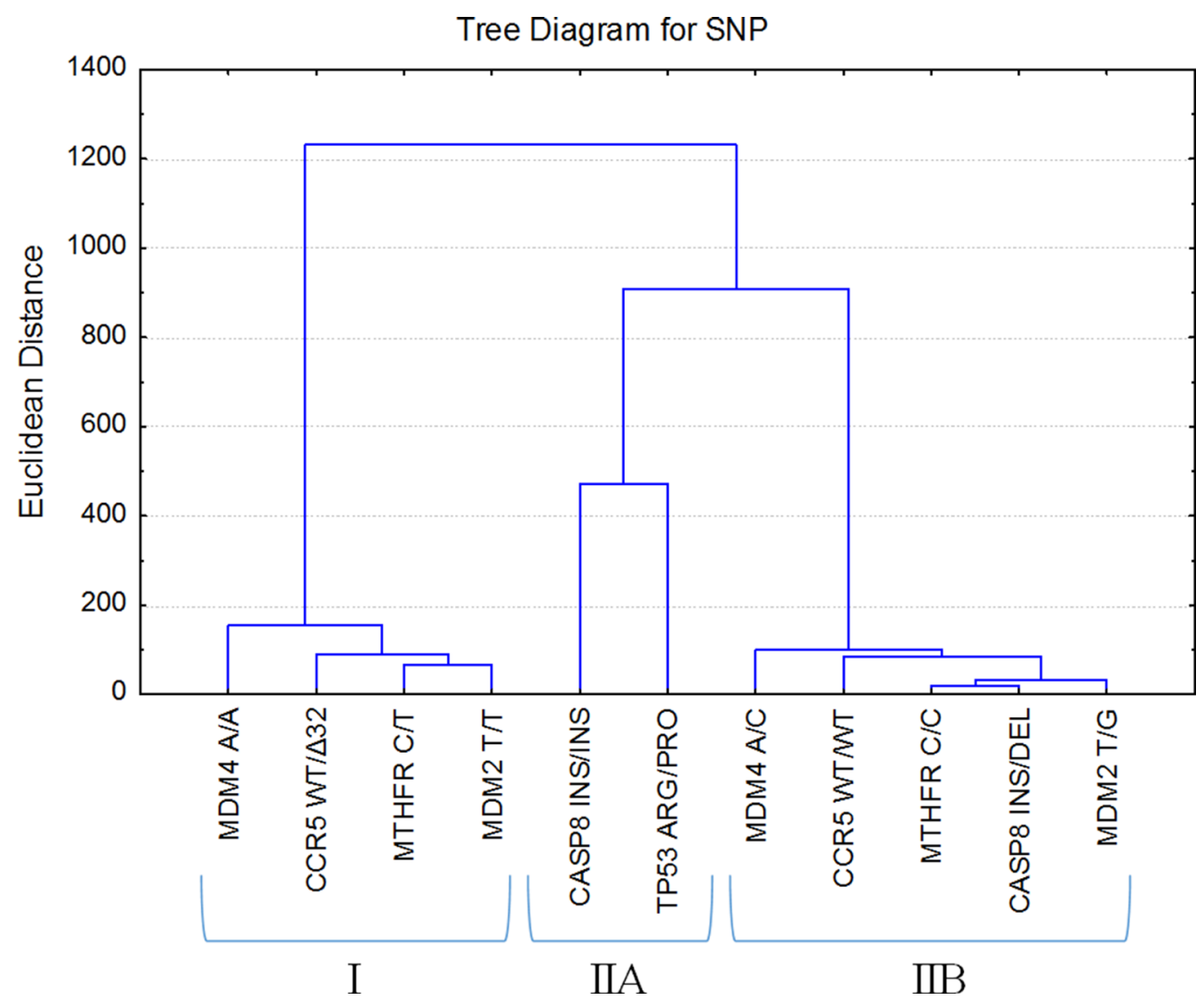

Figure 3: SNP clustering on the average survival median $\left(\mathbf{q}_{1}-\mathbf{q}_{3}\right)$ and mortality rates. Euclidian distances and Ward's method were used for groups merging. SNP average survival median chart was formed on patients who were identified with $M D M 4 \mathrm{~A} / \mathrm{A}, \mathrm{CCR} 5$ wt/ 32 , MTHFR C/T, MDM2 T/T, CASP8 ins/ins, TP53 Arg/Pro, MDM4 A/C, CCR5 wt/wt, MTHFR C/C, CASP8 ins/del, and MDM2 T/G polymorphic variants. 
Table 2: SNP-dependent survival rate (\%) in group of patients who did not survive until the end of the study

\begin{tabular}{|c|c|c|c|c|c|c|c|c|c|c|c|}
\hline \multirow{2}{*}{$\begin{array}{c}\text { Cluster } \\
\text { SNP }\end{array}$} & \multicolumn{4}{|c|}{ I } & \multicolumn{2}{|c|}{ IIA } & \multicolumn{5}{|c|}{ IIB } \\
\hline & $\begin{array}{c}\text { MDM4 } \\
\mathbf{A} / \mathbf{A}\end{array}$ & $\begin{array}{c}C C R 5 \\
w t / \Delta 32\end{array}$ & $\begin{array}{c}\text { MTHFR } \\
\mathrm{C} / \mathrm{T}\end{array}$ & $\begin{array}{c}M D M 2 \\
\text { T/T }\end{array}$ & $\begin{array}{l}\text { CASP8 } \\
\text { ins/ins }\end{array}$ & $\begin{array}{c}\text { TP53 } \\
\text { Arg/Pro }\end{array}$ & $\begin{array}{c}\text { MDM4 } \\
\mathrm{A} / \mathrm{C}\end{array}$ & $\begin{array}{l}\text { CCR5 } \\
\text { wt/wt }\end{array}$ & $\begin{array}{c}\text { MTHFR } \\
\text { C/C }\end{array}$ & $\begin{array}{l}\text { CASPB } \\
\text { ins/del }\end{array}$ & $\begin{array}{c}M D M 2 \\
\text { T/G }\end{array}$ \\
\hline$\%^{*}$ & 40.7 & 30.7 & 39.4 & 43.4 & 42.3 & 42.5 & 43.3 & 43.4 & 43.3 & 40.0 & 38.4 \\
\hline $\begin{array}{c}\mathbf{M}^{* *} \\
(\mathrm{IQR})\end{array}$ & $\begin{array}{c}355 \\
(353)\end{array}$ & $\begin{array}{c}413 \\
(492)\end{array}$ & $\begin{array}{c}375 \\
(518)\end{array}$ & $\begin{array}{c}437 \\
(516)\end{array}$ & $\begin{array}{c}723 \\
(716)\end{array}$ & $\begin{array}{c}711 \\
(153)\end{array}$ & $\begin{array}{c}572 \\
(416)\end{array}$ & $\begin{array}{c}498 \\
(437)\end{array}$ & $\begin{array}{c}557 \\
(423)\end{array}$ & $\begin{array}{c}542 \\
(412)\end{array}$ & $\begin{array}{c}572 \\
(398)\end{array}$ \\
\hline
\end{tabular}

${ }^{*}$ Mortality rate

${ }^{* *}$ Survival median $\left(\mathrm{IQR}\left(\mathrm{Q}_{3-} \mathrm{Q}_{1}\right)\right)$.

detailed analysis has shown that $\mathrm{C} / \mathrm{T}$ polymorphism of the MTHFR gene and T/T polymorphic variant of MDM2 gene are the most closely correlated with the poor survival of patients. The rate of both genes MTHFR $\mathrm{C} / \mathrm{T}\left(\chi^{2}=2.4\right.$, $\mathrm{df}=1, P=.12)$ and $M D M 2 \mathrm{~T} / \mathrm{T}(\chi 2=2.6, \mathrm{df}=1, P=$ .11) had a tendency to decrease in samples of patients diagnosed with stage III-IV cancer. This could be attributed to the worse survival of patients in the early stages of the disease. Therefore, it is worthwhile to check an importance of these genes in the first stages of the disease and in the period after the surgical treatment. Our results showed that the combination of polymorphic variants $\mathrm{C} / \mathrm{T}$ of the MTHFR gene and T/T of the MDM2 gene are significantly linked to the poor survival of LC patients after surgery $(P=.04)$. Meanwhile, individual SNPs of genes have no significant effect on the survival of patients after surgery: MTHFR $\mathrm{C} / \mathrm{T}(P=.38), M D M 2 \mathrm{~T} / \mathrm{T}(P=.49)$. Moreover, no significant link $(P=.96)$ was detected between the combination of MDM2 T/T, MTHFR $\mathrm{C} / \mathrm{T}$ and combinations of other polymorphic variants of MDM2 and MTHFR genes in regard to survival of LC patients after chemotherapy or other treatments strategies applied. Patients with $M D M 2$ $\mathrm{T} / \mathrm{T}$ and MTHFR $\mathrm{C} / \mathrm{T}$ and who underwent surgery had $37.5 \%$ survival rate for one year, while it was $90.0 \%$ for patients with the same combination of SNPs and who received chemotherapy. Significance of the tested genes SNPs for the survival of lung cancer patients analysed with Cox model has not showed the single SNP effect, but SNPs combination of genes MDM2 T/T, MTHFR C/T $(P=.14)$ along with the stage of patients with lung cancer $(P=.02)$ were associated with different periods of survival of lung cancer patients (Figure 4).

\section{HPV phylogenetic line identification}

After PCR analysis HPV infection was identified only in 3 tumor samples of all $92 \mathrm{LC}$ patients (3.3\%). In one case HPV of A9 phylogenetic line (showing infection of $16,31,33,35,52,58$ types of HPV) was identified, in the other A5/A6 (51 and 56 types of HPV) was detected.
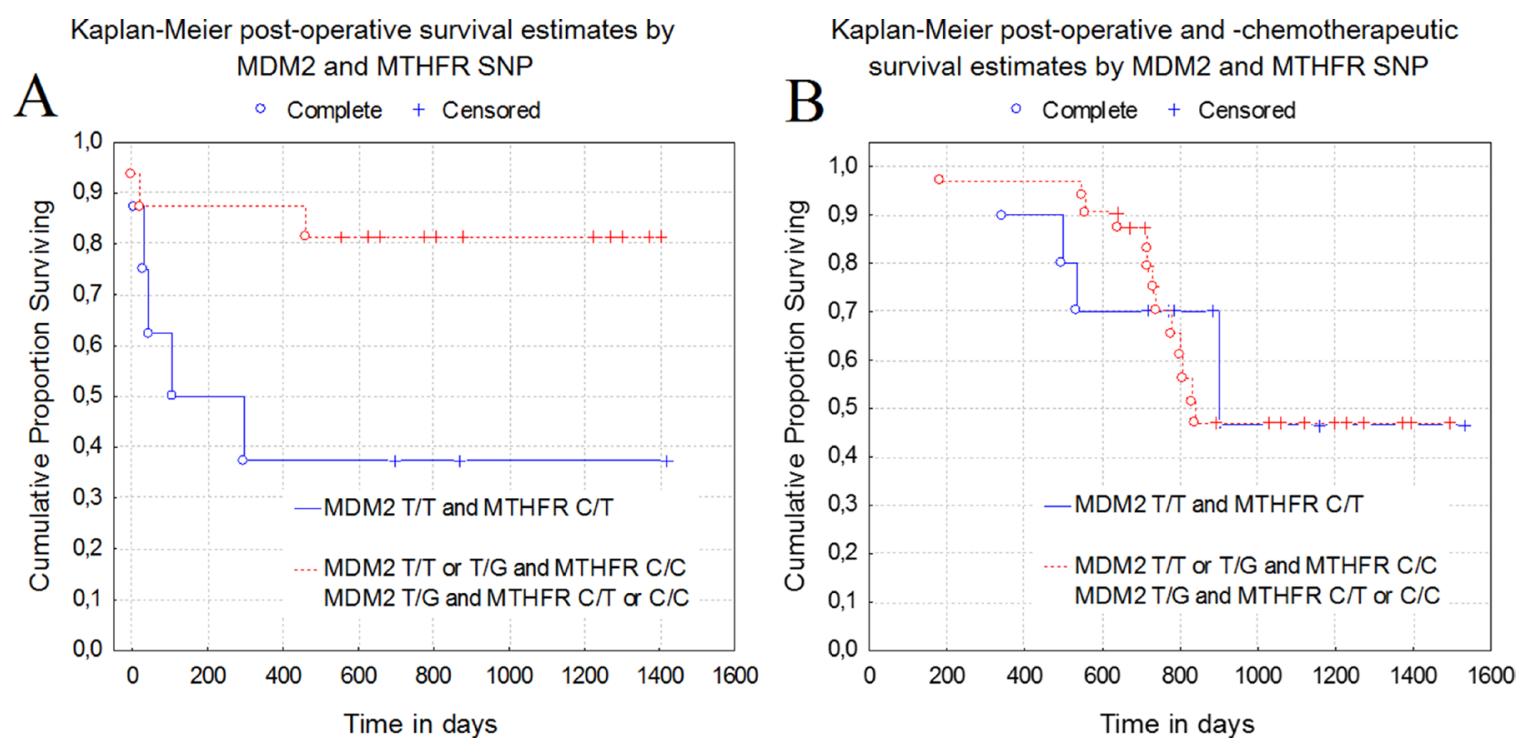

Figure 4: Relation between the survival and the combination of $M T H F R, M D M 2$ genes polymorphic variants. (A) Combination of MTHFR $\mathrm{C} / \mathrm{T}$ and $M D M 2 \mathrm{~T} / \mathrm{T}$ was significantly related to the poor patient survival after lung cancer surgery $(P=.04)$. $(\mathbf{B})$ - No significant link $(P=.96)$ was detected between the combination of MDM2 T/T, MTHFR C/T and combinations of other polymorphic variants of MDM2 and MTHFR genes in regard to survival of LC patients after chemotherapy or other therapeutic treatment. 
Table 3: Analysis of TP53, MDM2, MDM4, MTHFR, CASP8, CCR5-432 genes polymorphic variants of HPV positive lung cancer patients

\begin{tabular}{|c|c|c|c|c|c|c|c|c|c|c|c|c|c|c|c|c|c|c|c|c|}
\hline \multirow[b]{2}{*}{ "̈ } & \multirow{2}{*}{ 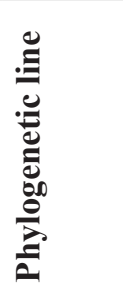 } & \multirow{2}{*}{ 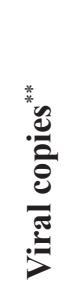 } & \multicolumn{3}{|c|}{$\begin{array}{c}T P 53 c .215 \\
\text { G }>C \\
\text { (Arg72Pro) } \\
\end{array}$} & \multicolumn{3}{|c|}{$\begin{array}{c}M D M 2 c .5+309 \\
G>T\end{array}$} & \multicolumn{3}{|c|}{$\begin{array}{c}M D M 4 c .1 \mathrm{q} 32 \\
\mathrm{~A}>\mathrm{C}\end{array}$} & \multicolumn{3}{|c|}{$\begin{array}{c}\text { MTHFRc.677 } \\
\text { C }>\text { T }\end{array}$} & \multicolumn{3}{|c|}{$\begin{array}{c}C A S P 8 c .-652 \\
6 \mathrm{~N} \text { ins/del }\end{array}$} & \multicolumn{3}{|c|}{ CCR5c. $-\triangle 32$} \\
\hline & & & $\sum_{\substack{\infty \\
\frac{0}{4}}}^{\infty}$ & 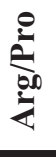 & 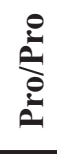 & 5 & $\stackrel{\vartheta}{E}$ & $\sum_{U}^{D}$ & $\ll$ & $\frac{Y}{4}$ & $\underset{\circlearrowright}{\circlearrowright}$ & $\stackrel{\circlearrowright}{\circlearrowright}$ & $\frac{v}{v}$ & 5 & 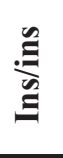 & $\frac{\bar{d}}{\tilde{g}}$ & $\begin{array}{l}\bar{d} \\
\overline{0} \\
\overline{0}\end{array}$ & $\frac{1}{k}$ & 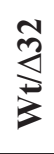 & 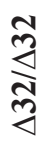 \\
\hline 1 & A9 & 0.98 & & & & & & & & & & & & & & & & & & \\
\hline 2 & A9,A7 & 2.7 & & & & & & & & & & & & & & & & & & \\
\hline 3 & $\mathrm{~A} 5 / 6$ & 2.2 & & & & & & & & & & & & & & & & & & \\
\hline
\end{tabular}

*Patient identification number

${ }^{* *}$ Number of copies of the virus expressed as lg HPV copy/cell.

In the third sample infection with two A9 and A7 (18, 39, 45, 59 types of HPV) phylogenetic lines were stated. However, the exact type of virus was not specified. But in all three samples the viral copy number in the cell was determined. In sample with A9 phylogenetic line the number of virus copies was $0.98 \mathrm{lg}$ HPV copy/cell, in sample with A5/A6 phylogenetic lines the viral load comprised $2.2 \mathrm{lg}$ HPV copy/cell. And in sample with two A9 and A7 phylogenetic lines number of virus copies amounted to $2.7 \mathrm{HPV}$ copy/cell. It is interesting to note that two out of three patients who were identified as HPV infected were smokers. One smoker was infected with A9, another with both A9 and A7 phylogenetic line viruses. Men patients harbored A9 HPV, whereas women A9, A7, A5/A6 HPV phylogenetic lines. Moreover, in all three HPV positive samples TP53c.215 G>C Arg/ Pro, CASP 8c. $-6526 \mathrm{~N}$ ins/del, and CCR5- $\triangle 32 \mathrm{wt} / \mathrm{wt}$ polymorphic variants were detected. In the sample with A7 and A9 phylogenetic line viruses MDM4 A/A and MTHFR C/C SNPs were identified. Others SNPs are shown in Table 3.

\section{DISCUSSION}

Literature research data on relationship between SNPs of genes TP53c.215 G>C (Arg72Pro), MDM2c.-5 + $309 \mathrm{G}>\mathrm{T}$, MDM4c.1q32 A $>\mathrm{C}$, MTHFRc.677 C $>\mathrm{T}-652$, $C A S P 8$ c.6N ins/del, CCR5- $\triangle 32$ and patients with LC survival rates were highly controversial. All our samples of LC patients were investigated to identify TP53c.215 $\mathrm{G}>\mathrm{C}$ (Arg72Pro), MDM2c.-5+309 G>T, MDM4c.1q32 A $>$ C, MTHFRc.677 C $>$ T-652, CASP8c. $6 \mathrm{~N}$ ins/del, and CCR5- $\triangle 32$ genes polymorphic variants.

Our study showed that heterozygous Arg/Pro polymorphic variant of gene TP53c.215 G>C (Arg72Pro) dominates and the frequency distribution is as follows: Arg/Pro $95.65 \%$, Arg/Arg 4.35\%. The high difference in the distribution of these alleles was shown in other populations: in the Iranian population, gene TP53 Arg/Arg,
Arg/Pro, Pro/Pro frequencies were respectively $42.6 \%$, $49.6 \%$, and $7.8 \%$ [42], while in the Korean population respectively $37.0 \%, 46.2 \%$, and $16.7 \%$ [43]. Sreeja et al. Kaplan-Meier survival analysis showed a significant difference in LC patients' survival between TP53 variant genotypes and overall survival. Cox regression analysis showed $p 53$ Arg72Pro heterozygous genotype was overall an independent prognostic factor, suggesting Pro72Pro genotype to be a potential risk factor favoring the development of lung carcinoma [44].

Published data on the association between MDM2 $309 \mathrm{~T} / \mathrm{G}$ polymorphism and risk for LC development are inconclusive [45]. Javid et al. revealed that MDM2 gene $\mathrm{G} / \mathrm{G}$ polymorphic variant might be associated with increased expression of $M D M 2$, which operates p53 expression changes [46]. Chua et al. published a study of Singaporean non-smokers LC patients. It was revealed that in female samples not the $\mathrm{G} / \mathrm{G}$, but $\mathrm{T} / \mathrm{T}$ polymorphism in position 309 of gene $M D M 2$ increases the risk 2.1 times, and combination with the TP53 Pro/Pro allele increases the risk 2.5 times. There was, however, no effect of either polymorphism on age at diagnosis of LC or on overall survival [47]. Enokida et al. published a case-control study showing gene $M D M 2 \mathrm{~T} / \mathrm{T}, \mathrm{T} / \mathrm{G}$, $\mathrm{G} / \mathrm{G}$ polymorphic variants frequencies in samples to be $21.1 \%, 49.7 \%$, and $30.2 \%$, respectively [48]. Our study polymorphisms frequencies of MDM2c.-5+309 G>T gene $\mathrm{T} / \mathrm{T}, \mathrm{T} / \mathrm{G}, \mathrm{G} / \mathrm{G}$ showed that $\mathrm{T} / \mathrm{T}$ polymorphic variant dominates and frequencies are $50.00 \%, 43.48 \%, 6.52 \%$, respectively. Dong et al. found that the MDM2 SNP309 (rs2279744) GT/TT genotypes are associated with a significantly worse survival [49]. Enokida et al. found that the overall survival of adenocarcinoma patients with pathological stage I disease and the MDM2 T/T genotype was significantly shorter than that of those with the $\mathrm{T} / \mathrm{G}$ or $\mathrm{G} / \mathrm{G}$ genotypes $(P=.02)[50]$. Our study showed no difference in mortality rate of patients harbouring gene MDM2 T/G or T/T polymorphic variant (respectively $38.4 \%$ and $43.4 \%$ ). The similar tendency is observed in 
the assessment of survival time (respectively 572 and 437 days). However, patients with advanced stages of LC and $\mathrm{T} / \mathrm{T}$ variant of the $M D M 2$ gene has the worst overall survival rate in the end of follow-up, but data were not statistically significant (Figure 2).

Analyses suggested that the rs4245739 polymorphism was significantly associated with overall cancer risk [51]. In Yang et al. study rs4245739 A/C genotype showed increased overall survival of LC patients in comparison to those with $\mathrm{A} / \mathrm{A}$ genotype $(P=.04)$ [52] Our research results indicate that $\mathrm{A} / \mathrm{A}$ polymorphic variant of gene $M D M 4 \mathrm{c} .1 \mathrm{q} 32 \mathrm{~A}>\mathrm{C}$ dominates in $\mathrm{LC}$ samples. The frequency of $\mathrm{A} / \mathrm{A}, \mathrm{A} / \mathrm{C}, \mathrm{C} / \mathrm{C}$ distribution is respectively $59.8 \%, 32.6 \%$, and $7.6 \%$. We showed that for patients identified with gene $M D M 4 \mathrm{~A} / \mathrm{A}$ SNP mortality rate is lower than with A/C (A/A 40.7\%, A/C 43.3\%). Patients with A/A polymorphic variant have 1.6 times shorter survival rate after surgery compared with patients who were identified with $\mathrm{A} / \mathrm{C}$ polymorphic form (355 days for $\mathrm{A} / \mathrm{A}$ and 572 days for $\mathrm{A} / \mathrm{C}$ ). However, the data also were not statistically significant.

Definite conclusions cannot be drawn from studies analysing the relation between MTHFR C677T polymorphism and LC risk [53, 54, 28, 55]. Cui et al. determined frequencies of MTHFRc.677 polymorphic $\mathrm{C} / \mathrm{C}, \mathrm{C} / \mathrm{T}, \mathrm{T} / \mathrm{T}$ variants to be $34.5 \%, 48.5 \%$, and $17.0 \%$, respectively. MTHFR $677 \mathrm{C} / \mathrm{T}$ and T/T genotypes showed a weak protective effect on LC development, compared with homozygous $\mathrm{C} / \mathrm{C}$ genotype, although these results were not statistically significant [56]. Cheng et al. showed MTHFRc.677 C>T polymorphic variants $\mathrm{C} / \mathrm{C}, \mathrm{C} / \mathrm{T}, \mathrm{T} / \mathrm{T}$ distribution to be respectively $27.7 \%, 35.1 \%, 37.2 \%$ and found T/T genotype link with LC [69]. Al-Motassem et al. established distribution of MTHFRc.677 C>T polymorphic variants as follows: C/C 59.6\%, C/T 33.0\%, and $\mathrm{T} / \mathrm{T} 7.4 \%$. Authors announced that patients who have $\mathrm{C} / \mathrm{C}$ polymorphic variant also have an increased risk for LC [57]. Similar results on MTHFRc.677 C>T SNP distribution in LC patients were showed in our study: $\mathrm{C} / \mathrm{C}$ polymorphic variant was dominating in our samples, $\mathrm{C} / \mathrm{C}$, $\mathrm{C} / \mathrm{T}, \mathrm{T} / \mathrm{T}$ polymorphisms frequencies were respectively $58.7 \%, 37.0 \%$, and $4.4 \%$. However, for our patients who were identified with MTHFR $\mathrm{C} / \mathrm{T}$ gene polymorphic variant mortality rate is almost the same as for those with $\mathrm{C} / \mathrm{C}$ polymorphic variant (39.4\% and $43.3 \%$, respectively), but their survival time stands out (respectively 375 and 557 days). Moreover, patients with advanced cancer stages (III-IV) and harbouring C/T polymorphism of the MTHFR gene had the shortest survival rate in regard to other MTHFR SNP variants $(\chi 2=2.4, P=.12, \mathrm{df}=1)$. This difference was not statistically significant as well.

In the analysed literature, SNPs studies of CASP8 $-6526 \mathrm{~N}$ gene have shown no clear association with LC. Sun et al. showed that CASP8 $-6526 \mathrm{~N}$ del polymorphism is associated with decreased LC development risk in China's population [58]. Ji et al. found that patients with CASP8 $-6526 \mathrm{~N}$ del polymorphism have greater susceptibility for LC development [32]. In our study, CASP8c. 6N-652 ins/del polymorphic ins/ins, ins/del, del/del polymorphisms frequency analysis showed that ins/del dominates and frequencies are respectively $28.3 \%, 66.3 \%$, and $5.4 \%$. We showed that mortality rate is lower for patients identified with CASP8 ins/del polymorphic form $(40.0 \%)$ than for patients with ins/ins polymorphic variant $(42.3 \%)$, but they survived shorter (542 days) than patients who were identified as ins/ins polymorphic variants (723 days).

To our best knowledge, there are no literature data on $C C R 5-\triangle 32$ polymorphic variants interface with LC development. It is known that patients identified with $C C R 5-\triangle 32 / \triangle 32$ genotype have a 4.58 times higher risk for HPV infection [35]. Due to these reasons, we analysed possible combined effect of HPV infection and CCR5- $\triangle 32$ in $\mathrm{LC}$ cancerogenesis. Our results indicated that wt/wt polymorphic variant of gene $C C R 5-\triangle 32$ dominates in samples and $w t / w t, w t / \Delta 32, \Delta 32 / \Delta 32$ frequency distribute respectively $83.7 \%, 14.1 \%$, and $2.2 \%$. We showed that for patients identified with gene CCR5 wt/ $\triangle 32$ polymorphic variant mortality rate is lower $(30.7 \%)$ than for wt/wt polymorphic form (43.4\%), and their survival is lower (413 days) than for patients identified with wt/ wt polymorphic form (498 days). HPV infection, as mentioned above, was found only in 3 analysed samples, so statistical analysis of combined effect on HPV and analysed genes SNPs was not performed.

Other authors published several studies on combined effect of different SNPs and effect on LC development and disease progression. One of the study showed that combined TP53 Pro/Pro and MDM2 G/G genotypes had a supermultiplicative interaction with respect to lung adenocarcinoma risk [59]. P53 pathway offers multiple molecular targets for screening small molecules as potential cancer therapies. Within the past decade number of new small molecules has been identified to target $p 53$, MDM2 or MDM4 polymorphic variants, some of which have been further advanced to the stage of clinical trials [60]. SNPs investigated in our study could be used as molecular targets in drug screening for potential novel LC therapies. Overall, detection of different polymorphic variants could help the physicians to evaluate more precisely the prognosis of LC patients or to apply more specific therapy, however, many authors conclude that these observations require further investigations with larger groups in order to identify potential markers for LC better prognosis and targeted therapy.

Combined effect of MTHFR and other genes (TS and $E R C C 1$ ) polymorphisms on effectiveness in first-line platinum and pemetrexed therapy in NSCLC patients was evaluated in Poland $[70,71]$. Authors showed that early LC progression was observed significantly more frequent in patients with $\mathrm{T} / \mathrm{T}$ genotype than in patients with $\mathrm{C} / \mathrm{C}$ or $\mathrm{C} / \mathrm{T}$ genotypes of $M T H F R \quad 677 \mathrm{C}>\mathrm{T}$ polymorphism, 
however, progression-free and overall survival were not affected by MTHFR gene polymorphism. After combined analysis of TS VNTR (variable number of tandem repeats)and MTHFR $677 \mathrm{C}>\mathrm{T}$ polymorphisms, a shorter progression-free survival in patients harboring $\mathrm{C} / \mathrm{C}$ in MTHFR gene was shown [70]. Later authors concluded that carriers of $3 \mathrm{R}$ in $T S$ gene and $\mathrm{C} / \mathrm{C}$ genotype of MTHFR gene have significantly shorter overall survival $(\mathrm{HR}=3.07 ; P=.003)$ and significantly higher risk of death $(\mathrm{HR}=3.85 ; P<.005)[71]$. Earlier Smit et. al [72] showed, that LC patients with $\mathrm{T} / \mathrm{T}$ polymorphic variant of $M T H F R$ gene have longer progression-free survival time compared to patients with $\mathrm{C} / \mathrm{C}$ or $\mathrm{C} / \mathrm{T}$ polymorphic variants. $L i$ et. al [73] showed that MTHFR heterozygotes yield better clinical benefit $(P=.03)$ after platinum based chemotherapy, however, overall survival and progression-free survival of LC patients do not differ regarding MTHFR polymorphic variants. In our study we performed cluster analysis which showed that the combination of MTHFR C/T and MDM2 $\mathrm{T} / \mathrm{T}$ are significantly linked to the poor survival of LC patients after surgery $(P=.04)$. However, the effect of SNPs of our investigated genes on the effectiveness of chemotherapy was not evaluated in our study. Nevertheless, genetic factors (alone or in combination) may have a high predictive and prognostic value for LC survival after surgery or chemotherapy applied.

Regarding viral infection and lung cancer, the first evidence that there is a link between HPV infection and bronchial lesions was determined in 1979 by Rubel and Reynolds [2]. Syrjänen et al. in 1979 introduced the idea that HPV infection may be one of the factors involved in process of lung carcinogenesis [41]. Over the past years, several studies analysing HPV infection and LC were carried out. HPV infection is established from $0 \%$ to $36 \%$ in patients of Western world with lung adenocarcinoma and from $9 \%$ to $78 \%$ in Asia population [38]. Recently, Sarchianaki et al. survey data showed that HPV types identified in LC patients could be such as $16,11,33,31,18,6,59$. The most commonly found type is $16(42.1 \%)$ and $11(15.8 \%)$ [61]. In our study, 2 out of 3 patients with HPV identified in LC samples were females, one infected with A9, A7, A5/ A6 phylogenetic line HPV, and the other one harboured viruses belonging to two phylogenetic groups. Based on these findings we suppose that HPV could spread from cervical epithelium through blood or lymph. However, we did not test cervical HPV infection and exact type of the virus for these women. In all three HPV-positive samples TP53c.215 G>C Arg/Pro, CASP8c.-652 6N ins/ del, CCR5- $\triangle 32 \mathrm{wt} / \mathrm{wt}$ polymorphic variants occurred. Jain et al. study of India's population showed that out of 40 LC patients 2 were infected with HPV and were identified with TP53c.215 G>C (Arg72Pro) gene Arg/ Arg polymorphic variant (apart from patients with confirmed lung IV cancer stage, Arg/Pro polymorphic variant dominated in these samples) [62]. Lately, Amaral et al. connection analysis of cervical lesions, HPV, oral contraceptive, and MDM2c.-5+309 G>T polymorphism found that there is a link between highgrade cervical lesions, contraceptive use, and MDM2 gene $\mathrm{T} / \mathrm{G}$ polymorphic variant [63]. To our knowledge, we are the first to analyze the interactions between MDM2c.-5+309 G>T, MDM4c.1q32 A>C, MTHFRc.677 C $>$ T-652, CASP8c. $6 \mathrm{~N}$ ins/del, CCR5- $\triangle 32$ polymorphic variants, lung cancer, and HPV. Unfortunately, due to the small number of HPV infected patients in our study it was not possible to evaluate combined effect of HPV infection and different genes polymorphisms on the survival of LC patients. Therefore, here we conducted a study of TP53c.215 G>C (Arg72Pro), MDM2c.-5+309 $\mathrm{G}>\mathrm{T}, M D M 4 \mathrm{c} .1 \mathrm{q} 32 \mathrm{~A}>\mathrm{C}$, MTHFRc.677 C $>\mathrm{T}-652$, $C A S P 8$ c. $-6526 \mathrm{~N}$ ins/del, and CCR5- $\triangle 32$ polymorphic variants frequency analysis in LC samples $(n=92)$, regardless of the HPV infection. It is worthwhile to continue research in this direction with larger patient groups in order to clarify HPV implication in LC.

Finally, there is a link between specific SNPs and LC patient survival frequency and time, meanwhile the combination of specific SNPs showed a statistically significant measure. In conclusion, statistically significant $(P=.04)$ link was determined between the poor survival of LC patients after surgery with combination of polymorphic variants $\mathrm{C} / \mathrm{T}$ of the MTHFR and $\mathrm{T} / \mathrm{T}$ of the $M D M 2$ genes, whereas individually these SNPs do not show significant relationship with our LC patients survival. However, it is important to notice that genetic factors (alone or in combination) may have a high predictive and prognostic value for LC survival after different treatments strategies applied.

\section{MATERIALS AND METHODS}

\section{Study subjects and design}

In the period from September of 2012 to December of 201492 patients (76 male and 16 female) with diagnosis of primary LC from Department of Thoracic Surgery at the National Cancer Institute (Vilnius, Lithuania) were asked to participate in the study. Study protocol was accepted by the Vilnius Regional Committee for the Biomedical Research (11-06-2013 No. 158200-13-638-204). All patients signed Informed consent before the surgery. Patients were included into the study according to the following criteria: all of them had primary lung cancer and none of them had received radiotherapy or chemotherapy prior to surgery. After surgery all tumors were examined by the pathologist and the diagnosis was confirmed by expert pathologists. Remaining material after the diagnosis was collected to the Biobank at the National Cancer Institute and stored till the scientific examination. All samples previously 
had been analyzed for the presence of HPV. Then the SPN analysis of various previously described genes was performed.

\section{DNA extraction}

DNA was purified by organic extraction method according to the approved standard operating procedures at the Biobank of the National Cancer Institute. Firstly, after pathology diagnosis, all tumor tissue samples were cut into small pieces $(30-50 \mathrm{mg}$ ) and were snap froze in the liquid nitrogen. Control cut was also performed for the evaluation of amount of cancer cells in the sample. Before DNA extraction tumor sample was crushed and melted in liquid nitrogen. Melted material was placed in a test-tube, lysis buffer $(50 \mathrm{mM}$ Tris $\mathrm{HCl}, \mathrm{pH} 8.0 ; 200 \mathrm{mM}$ $\mathrm{NaCl} ; 20$ mM EDTA, $\mathrm{pH} 8.0,1 \%$ SDS) and proteinase $\mathrm{K}$ solution $(10 \mathrm{mg} / \mathrm{ml})$ were added. Tube was incubated in $55^{\circ} \mathrm{C}$ for 12 hours. DNA purification was carried out with phenol-chloroform solutions and precipitation with $70 \%$ and $96 \%$ ethanol solutions. After that DNA was dried. Later the dried DNA was dissolved in $500 \mu \mathrm{l}$ of sterile distilled water at $4^{\circ} \mathrm{C}$. DNA purification quality was measured using spectrophotometer (NanoDrop ${ }^{\mathrm{TM}}$ 2000, Thermo Scientific). The quantitative DNA analysis was performed by measuring optical density at $280 \mathrm{~nm}$ wavelength. According to the ratio of A260/A280, isolated DNA of all samples used in this study was of adequate quality being in a range from 1.7 to 1.9 .

\section{Genotype analysis}

From each tumor sample extracted DNA was used for PCR analysis of TP53 Arg72Pro (rs1042522), CASP8-652 6N (rs3834129), and CCR5 $\triangle 32$ (rs333) genes. For gene TP53 Arg72Pro (rs1042522) allele 4 different specific primers were used: Arg allele forward: $5^{\prime} \rightarrow$ TCCCCCTTGCCGTCCCAA $\rightarrow 3^{\prime}$ and reverse: $5^{\prime} \rightarrow$ CTGGTGCAGGGGCCACGC $\rightarrow 3$, Pro allele forward: $5^{\prime} \rightarrow$ GCCAGAGGCTGCTCCCCCC $\rightarrow 3^{\prime}$ and reverse: $5^{\prime} \rightarrow$ CGTGCAAGTCACAGACTT $\rightarrow 3^{\prime}$, which had revealed the following results of $141 \mathrm{bp}$ and $177 \mathrm{bp}$ products [64]. Likewise, for CASP8-652 $6 \mathrm{~N}$ (rs3834129) gene 2 primers were used: forward: $5^{\prime} \rightarrow$ AGTGAAAACTTCT CCCATGGCCTC $\rightarrow 3^{\prime}$ and reverse: $5^{\prime} \rightarrow$ GATTGATACTG GCACAGTATACTTACC $\rightarrow 3^{\prime}$, and two specific primers: (Insertion allele): 5' $\rightarrow$ GTAATTCTTGCT CTGCCAAGCTG $\rightarrow 3^{\prime}$; (Deletion allele) $5^{\prime} \rightarrow$ CCAAGGTCA CGCAGCTAGTAAG $\rightarrow 3^{\prime}$, which had revealed the following results of $139 \mathrm{bp}, 291 \mathrm{bp}$, and $396 \mathrm{bp}$ fragments [65]. And for $C C R 5-\triangle 32$ (rs333) gene 2 specific primers were used: forward: $\quad 5^{\prime} \rightarrow$ ACCTGCAGCTCTCATTTTCC $\rightarrow 3^{\prime} \quad$ and reverse: $5^{\prime} \rightarrow$ GCAGATGACCATGACAAGCA $\rightarrow 3^{\prime}$, which had revealed the results of $111 \mathrm{bp}$ and $79 \mathrm{bp}$ fragments [35]. After PCR reactions with specific primers, for product visualisation LabChip GX/GX II Touch (Perkin Elmer) capillary electrophoresis method was used to identify all studied genes polymorphic variants.

MDM2 T309G (rs2279744), MDM4 (rs4245739), and MTHFR (rs1801133) genotypes were determined by polymerase chain reaction - restriction fragment length polymorphism (PCR-RFLP). A 89 bp of fragment covering MDM2 gene was amplified by a set of primers: forward: $5^{\prime} \rightarrow$ TTCGGAGGTCTCCGCGGGAGTTCAG $\rightarrow 3^{\prime}$ and reverse: $5^{\prime} \rightarrow$ TGCGATCATCCGGACCTCCCGCGTC $\rightarrow 3^{\prime}$ [66]. The PCR product was digested with restriction enzyme TaqI (FastDigest Enzyme, Thermo Scientific) at $65^{\circ} \mathrm{C}$ for $8 \mathrm{~min}$. T/G genotype was identified by existence of $89 \mathrm{bp}, 64 \mathrm{bp}$, and $25 \mathrm{bp}$ fragments.
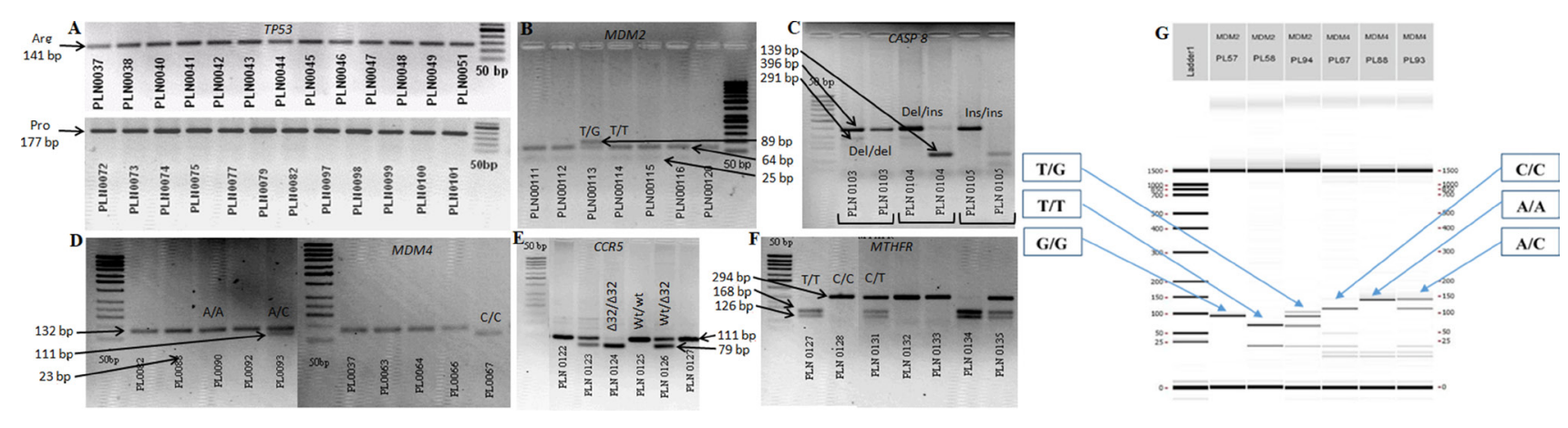

Figure 5: TP53, MDM2, MDM4, MTHFR, CASP8, and CCR5 genes polymorphic variants of lung tumor tissue using agarose electrophoresis and LabChip GX/GX II Touch capillary electrophoresis gel. (A) - TP53 polymorphic variants (141bp - Arg; 177bp - Pro). (B) - SNPs of gene MDM2 (89bp - G/G; 64bp, 25bp - T/T; 89bp, 64bp, 25bp - T/G). (C) - SNPs of gene CASP8 (396bp, $291 \mathrm{bp}$ - del/del; 396bp, 291bp, 139bp - del/ins; 396bp, 139bp - ins/ins). (D) - SNPs of gene MDM4 (132bp - A/A, 132bp, 111bp $\mathrm{A} / \mathrm{C}, 111 \mathrm{bp}-\mathrm{C} / \mathrm{C})$. (E) - SNPs of gene CCR5 (79bp - $\Delta 32 / \Delta 32 ; 111 \mathrm{bp}-\mathrm{wt} / \mathrm{wt} ; 111 \mathrm{bp}, 79 \mathrm{bp}-\mathrm{wt} / \Delta 32)$. (F) - SNPs of gene MTHFR $(168 \mathrm{pb}$, 126bp - T/T; 294bp - C/C; 294bp, 168bp, 126bp - C/T). (G) - MDM4 and MDM2 gene polymorphic variants of lung tumor tissue using LabChip GX/GX II Touch capillary electrophoresis method. On the left side MDM2c.-5 + 309G>T variants are showed: in PL57 sample G/G 89 bp was found; in PL58 sample two fragments of 64 bp and 25 bp were found, reflecting the presence of the T/T genotype; and all three bands $(89,64,25 \mathrm{bp})$ showed the presence of the T/G genotype in PL94 sample. On the right side MDM4c.1q32 A>C polymorphic variants are showed: A/A 132 bp (PL88 sample); C/C 111 bp, 23 bp (PL67 sample); A/C 132 bp, 111 bp, 23 bp (PL93 sample). 
The PCR product of gene MDM4 (forward primer: 5' $\rightarrow$ AAGACTAAAGAAGGCTGGGG $\rightarrow$ 3', reverse primer: $5 \rightarrow$ TTCAAATAATGTGGCAAGTGACC $\rightarrow 3^{\prime}$ ) (rs4245739) was digested with restriction enzyme MspI. Polymorphic variants were identified by existence of 134 bp, $111 \mathrm{bp}$, and 23 bp fragments [67]. Finally, the PCR product of gene MTHFR (rs1801133) (forward primer: 5' $\rightarrow$ CCTTGAACAGGTGGAGGCCAG $\rightarrow 3{ }^{\prime}, \quad$ reverse primer: 5' $\rightarrow$ GCGGTGAGAGTGGGGTGGAG $\rightarrow$ 3') [68] was digested with restriction enzyme Hinfl and the results of this study were fragments of $294 \mathrm{bp}, 168 \mathrm{bp}, 126 \mathrm{bp}$. All fragments were analysed by LabChip GX I Touch capillary electrophoresis and electrophoresis in agarose gel method. Example of fragments analysis is presented in the Figure 5.

\section{HPV A9, A7, and A5/A6 phylogenetic group detection}

Phylogenetic group of HPV, viral copy number, and the total number of copies of the virus in cells were determined by RT-PCR. AmpliSens HPV screen-titre-FRT PCR kit (AmpliSens) was used to determine HPV A9, A7, and A5/A6 phylogenetic groups. The kit was composed of PCR-mix-1FRT HPV A9, A7, and A5/A6 phylogenetic groups according to HPV E1 - E2 gene-based primers. In A9 phylogenetic line HPV types 16, 31, 33, 35, 52, 58; in A7 phylogenetic line HPV types 18, 39, 45, 59; and in phylogenetic line A5/A6 HPV types 51 and 56 were attributed. Amplification was performed using the Rotor-Gene $Q$ amplificator and RotorGene $Q$ software (version 2.1.9.9). Endogenic control with $\beta$ globin was performed for each PCR cycle. Number of copies of the virus in the cell was calculated using the formula: log (HPV DNA copies/human DNA copies) $\times 200,000=10 g$ (HPV of 100,000 cells).

\section{Statistical analysis}

Statistical comparisons among groups were performed by Chi-square test. Survival was estimated by Kaplan-Meier method. The statistical difference between the survival curves was determined using the log-rank test. The variables with $\log$-rank test $P$ value $<0.2$ were selected for Cox regression analysis. For SNPs analysis clusterisation in a multi-dimensional space (mortality rate; quartile 1 (Q1), median (M), and quartile 3 (Q3) of patient survival time) was performed computing Euclidean distances between objects and linking several objects by Ward's method. A $P$ value of $<.05$ was considered statistically significant. Statistical analysis was performed using SigmaPlot 12.3 and STATISTICA 10.0 software.

\section{ACKNOWLEDGMENTS}

The authors would like to thank MD Renatas Askinis, MD Arnoldas Krasauskas, MD Sigitas Zaremba for patient enrollment.

\section{CONFLICTS OF INTEREST}

The authors have no conflicts of interest.

\section{GRANT SUPPORT}

This work was supported by The European Union and the Ministry of Education \& Science of the Republic of Lithuania grant "Development of training of highly qualified professionals satisfying the requirements of the state and society in the field of biomedicine BIOMEDOKT" (No. VP1-3.1-SMM-01-V-03-002).

\section{REFERENCES}

1. Zhang ZY, Xuan Y, Jin XY, Tian X, Wu R. A literaturebased systematic HuGE review and meta-analysis show that CASP gene family polymorphisms are associated with risk of lung cancer. Genet Mol Res. 2013; 12:3057-3069.

2. de Freitas AC, Gurgel AP, de Lima EG, de Franca São Marcos B, do Amaral CM. Human papillomavirus and lung carcinogenesis: an overview. J Cancer Res Clin Oncol. 2016; 142:2415-2427.

3. Torre LA, Bray F, Siegel RL, Ferlay J, Lortet-Tieulent J, Jemal A. Global cancer statistics. CA Cancer J Clin. 2012; 65:87-108.

4. Smailytė G, Aleknavičienė B. Vezys Lietuvoje 2012 metais. (NCI: Vilnius). http://www.nvi.lt/wp-content/ uploads/2016/04/Vezys_lietuvoje_2012.pdf.

5. Hensing T, Chawla A, Batra R, Salgia R. A personalized treatment for lung cancer: molecular pathways, targeted therapies, and genomic characterization. Adv Exp Med Biol. 2014; 799:85-117.

6. Provencio M, Isla D, Sánchez A, Cantos B. Inoperable stage III non-small cell lung cancer: Current treatment and role of vinorelbine. J Thorac Dis. 2011; 3:197-204.

7. Bah PB, Mirkin JN, Oliver TK, Azzoli CG, Berry DA, Brawley OW, Byers T, Colditz GA, Gould MK, Jett RJ, Sabichi AL, Smith-Bindman R, Wood DE, et al. Benefits and harms of CT screening for lung cancer: a systematic review. JAMA. 2012; 307:2418-2429.

8. Chen ZM, Peto R, Iona A, Guo Y, Chen YP, Bian Z, Yang L, Zhang WY, Lu F, Chen JS, Collins R, Li LM, China Kadoorie Biobank Collaborative Group. Emerging tobacco-related cancer risks in China: A nationwide, prospective study of 0.5 million adults. Cancer. 2015; 121 Suppl 17:3097-3106.

9. Yang P. Lung cancer in never smokers. Semin Respir Crit Care Med. 2011; 32:10-21.

10. Torok S, Hegedus B, Laszlo V, Hoda MA, Ghanim B, Berger W, Klepetko W, Dome B, Ostoros G. Lung cancer in never smokers. Future Oncol. 2011; 7:1195-1211.

11. Zhai K, Ding J, Shi HZ. HPV and lung cancer risk: A metaanalysis. J Clin Virol. 2015; 63:84-90.

12. Lind H, Zienolddiny S, Ekstrøm PO, Skaug V, Haugen A. Association of a functional polymorphism in the promoter 
of the MDM2 gene with risk of nonsmall cell lung cancer. Int J Cancer. 2006; 119:718-721.

13. Liu L, Wu C, Wang Y, Zhong R, Duan S, Wei S, Lin S, Zhang X, Tan W, Yu D, Nie S, Miao X, Lin D. Combined Effect of Genetic Polymorphisms in P53, P73 and MDM2 on Non-small Cell Lung Cancer Survival. J Thorac Oncol. 2011; 6:1793-1800.

14. Chen SP, Hsu NY, Wu JX, Chen CY, Chou MC, Lee H, Cheng YW. Association of p53 codon 72 genotypes and clinical outcome in human papillomavirus-infected lung cancer patients. 2012; 95:1196-1203.

15. Zhang X, Miao X, Guo Y, Tan W, Zhou Y, Sun T, Wang $\mathrm{Y}$, Lin D. Genetic polymorphisms in cell cycle regulatory genes MDM2 and TP53 are associated with susceptibility to lung cancer. Hum Mutat. 2006; 27:110-117.

16. Nag S, Qina J, Srivenugopal KS, Wang M, Zhang R. The MDM2-p53 pathway revisited. J Biomed Res. 2013; 27:254-271.

17. Wang Z, Sturgis EM, Zhang Y, Huang Z, Zhou Q, Wei Q, Li G. Combined p53-related genetic variants together with HPV infection increase oral cancer risk. Int J Cancer. 2012; 131:E251-E258.

18. Duffy MJ, Synnott NC, McGowan PM, Crown J, O’Connor D, Gallagher WM. p53 as a target for the treatment of cancer. Cancer Treat Rev. 2014;40:1153-60.

19. Shi D, Gu W. Dual Roles of MDM2 in the Regulation of p53: Ubiquitination Dependent and Ubiquitination Independent Mechanisms of MDM2 Repression of p53 Activity. Genes Cancer. 2012; 3:240-248. https://doi. org/10.1177/1947601912455199.

20. Zhuo W, Zhang L, Zhu B, Ling J, Chen Z. Association of MDM2 SNP309 variation with lung cancer risk: evidence from 7196 cases and 8456 controls. PLoS One. 2012; 7:e41546.

21. Gansmo LB, Romundstad P, Birkeland E, Hveem K, Vatten L, Knappskog S, Lønning PE. MDM4 SNP34091 (rs4245739) and its effect on breast-, colon-, lung-, and prostate cancer risk. Cancer Med. 2015; 4:1901-1907.

22. Biderman L, Manley JL, Prives C. Mdm2 and MdmX as Regulators of Gene Expression. Genes Cancer. 2012; 3:264-273. https://doi.org/10.1177/1947601912455331.

23. Botezatu A, Socolov D, Iancu IV, Huica I, Plesa A, Ungureanu C, Anton G. Methylenetetrahydrofolate reductase (MTHFR) polymorphisms and promoter methylation in cervical oncogenic lesions and cancer. J Cell Mol Med. 2013; 17:543-549.

24. Rai V. Folate pathway gene MTHFR C677T polymorphism and risk of lung cancer in Asian populations. Asian Pac J Cancer Prev. 2014; 15:9259-9264.

25. Yuan JM, Lu SC, Van Den Berg D, Govindarajan S, Zhang ZQ, Mato JM, Yu MC. Genetic polymorphisms in the methylenetetrahydrofolate reductase and thymidylate synthase genes and risk of hepatocellular carcinoma. Hepatology. 2007; 46:749-758.

26. Durda K, Kaklewski K, Gupta S, Szydlowski M, Baszuk P, Jaworska-Bieniek K, Sukiennicki G, Kaczmarek K,
Waloszczyk P, Narod S, Lubinski J, Jakubowska A. Serum folate concentration and the incidence of lung cancer. PLoS One. 2017; 12:e177441. https://doi.org/10.1371/journal. pone.0177441PONE-D-16-34113.

27. Xie SZ, Liu ZZ, Yu JH, Liu L, Wang W, Xie DL, Qin JB. Association between the MTHFR C677T polymorphism and risk of cancer: evidence from 446 case-control studies. Tumour Biol. 2015; 36:8953-8972.

28. Zhang XD, Li YT, Yang SY, Li W. Meta-analysis on MTHFR polymorphism and lung cancer susceptibility in East Asian populations. Biomed Rep. 2013; 1:440-446.

29. Long S, Yang X, Liu X, Yang P. Methylenetetrahydrofolate Reductase (MTHFR) Polymorphisms and Susceptibility for Cervical Lesions: A Meta-Analysis. PLoS One. 2012; 7:e52381.

30. Chen D, Ma T, Liu XW, Liu Z. CASP-8 $-6526 \mathrm{~N}$ ins/ del polymorphism and cancer risk: A literature-based systematic HuGE review and meta-analysis. Exp Ther Med. 2012; 4:762-770.

31. Liu D, Xu W, Ding X, Yang Y, Lu Y, Fei K, Su B. Caspase 8 polymorphisms contribute to the prognosis of advanced lung adenocarcinoma patients after platinum-based chemotherapy. Cancer Biol Ther. 2017:0. https://doi.org/1 0.1080/15384047.2016.1276128.

32. Ji GH, Li M, Cui Y, Wang JG. The relationship of CASP8 polymorphism and cancer susceptibility: a meta-analysis. Cell Mol Biol. 2014; 60:20-28.

33. Theodoropoulos GE, Gazouli M, Vaiopoulou A, Leandrou M, Nikouli S, Vassou E, Kouraklis G, Nikiteas N. Polymorphisms of caspase 8 and caspase 9 gene and colorectal cancer susceptibility and prognosis. Int $\mathrm{J}$ Colorectal Dis. 2011; 26:1113-1118.

34. Kesarwani P, Mandal RK, Maheshwari R, Mittal RD. Influence of caspases 8 and 9 gene promoter polymorphism on prostate cancer susceptibility and early development of hormone refractory prostate cancer. BJU Int. 2011; 107:471-476.

35. Zheng B, Wiklund F, Gharizadeh B, Sadat M, Gambelunghe G, Hallmans G, Dillner J, Wallin KL, Ghaderi M. Genetic polymorphism of chemokine receptors CCR2 and CCR5 in Swedish cervical cancer patients. Anticancer Res. 2006; 26:3669-3674.

36. Degerli N, Yilmaz E, Bardakci F. The delta32 allele distribution of the CCR5 gene and its relationship with certain cancers in a Turkish population. Clin Biochem. 2005; 38:248-252.

37. Ying H, Wang J, Gao X. CCL5-403, CCR5-59029, and Delta32 polymorphisms and cancer risk: a meta-analysis based on 20,625 subjects. Tumor Biol. 2014; 35:5895-5904.

38. Hsu NY, Lee H, Yen Y, Cheng YW. Human papillomavirus and non-small cell lung cancer. Thorac Cancer. 2013; 4:345-353.

39. Heng B, Glenn WK, Ye Y, Tran B, Delprado W, LutzeMann L, Whitaker NJ, Lawson JS. Human papilloma virus is associated with breast cancer. Br J Cancer. 2009; 101:1345-1350. 
40. Carpagnano GE, Koutelou A, Natalicchio MI, Martinelli D, Ruggieri C, Taranto AD, Antonetti R, Carpagnano F, Foschino-Barbaro MP. HPV in exhaled breath condensate of lung cancer patients. Br J Cancer. 2011; 105:1183-1190.

41. Syrjänen K. Detection of human papillomavirus in lung cancer: systematic review and meta-analysis. Anticancer Res. 2012; 32:3235-3250.

42. Nadji SA, Mahmoodi M, Ziaee AA, Naghshvar F, Torabizadeh J, Yahyapour Y, Nategh R, Mokhtari-Azad T. An increased lung cancer risk associated with codon 72 polymorphism in the TP53 gene and human papillomavirus infection in Mazandaran Province, Iran. Lung Cancer. 2007; 56:145-151.

43. Piao JM, Kim HN, Song HR, Kweon SS, Choi JS, Yun WY, Kim YC, Oh IJ, Kim KS, Shin MH. p53 codon 72 polymorphism and the risk of lung cancer in a Korean population. Lung Cancer. 2011; 73:264-267.

44. Sreeja L, Syamala V, Raveendran PB, Santhi S, Madhavan J, Ankathil R. p53 Arg72Pro polymorphism predicts survival outcome in lung cancer patients in Indian population. Cancer Invest. 2008; 26:41-6.

45. Gui XH, Qiu LX, Zhang HF, Zhang DP, Zhong WZ, Li J, Xiao YL. MDM2 $309 \mathrm{~T} / \mathrm{G}$ polymorphism is associated with lung cancer risk among Asians. Eur J Cancer. 2009; 45:2023-6.

46. Javid J, Mir R, Julka PK, Ray PC, Saxena A. Association of p53 and mdm 2 in the development and progression of nonsmall cell lung cancer. Tumour Biol. 2015; 36:5425-5432.

47. Chua HW, Ng D, Choo S, Lum SS, Li H, Soh LY, Sabapathy K, Seow A. Effect of MDM2 SNP309 and p53 codon 72 polymorphisms on lung cancer risk and survival among nonsmoking Chinese women in Singapore. BMC Cancer. 2010; 10:88.

48. Enokida Y, Shimizu K, Atsumi J, Kakegawa S, Takase Y, Kaira K, Yashima H, Araki T, Nakazawa S, Ohtaki Y, Nagashima T, Alexander L, Usui K, et al. Prognostic potential of the MDM2 309T $>$ G polymorphism in stage I lung adenocarcinoma. Cancer Med. 2016; 5:1791-1801.

49. Dong J, Ren B, Hu Z, Chen J, Hu L, Dai J, Jin G, Xu L, Shen H. MDM2 SNP309 contributes to non-small cell lung cancer survival in Chinese. Mol Carcinog. 2011; 50:433-438.

50. Enokida Y, Shimizu K, Kakegawa S, Atsumi J, Takase Y, Miyamae Y, Nagashima T, Ohtaki Y, Kaira K, Sunaga N, Yanagitani N, Yoshino R, Tsunekawa K, et al. Singlenucleotide polymorphism (c.309T $>$ G) in the MDM2 gene and lung cancer risk. Biomed Rep. 2014; 2:719-724.

51. Wang MJ, Luo YJ, Shi ZY, Xu XL, Yao GL, Liu RP, Zhao $\mathrm{H}$. The associations between MDM4 gene polymorphisms and cancer risk. Oncotarget. 2016; 7:55611-55623. https:// doi.org/10.18632/oncotarget.10877.

52. Yang Y, Gao W, Ding X, Xu W, Liu D, Su B, Sun Y. Variations within 3'-UTR of MDM4 gene contribute to clinical outcomes of advanced non-small cell lung cancer patients following platinum-based chemotherapy. Oncotarget. 2017; 8:16313-16324. https://doi.org/10.18632/oncotarget.10771.
53. Wang X, Yue K, Hao L. Meta-analysis of methylenetetrahydrofolate reductase polymorphism and lung cancer risk in Chinese. Int J Clin Exp Med. 2015; $8: 1521-1525$.

54. Siemianowicz K, Gminski J, Garczorz W, Slabiak N, Goss M, Machalski M, Magiera-Molendowska $\mathrm{H}$. Methylenetetrahydrofolate reductase gene C677T and A1298C polymorphisms in patients with small cell and nonsmall cell lung cancer. Oncol Rep. 2003; 10:1341-1344.

55. Liu CS, Tsai CW, Hsia TC, Wang RF, Liu CJ, Hang LW, Chiang SY, Wang CH, Tsai RY, Lin CC, Bau DT. Interaction of methylenetetrahydrofolate reductase genotype and smoking habit in Taiwanese lung cancer patients. Cancer Genomics Proteomics. 2009; 6:325-329.

56. Cui LH, Shin MH, Kim HN, Song HR, Piao JM, Kweon SS, Choi JS, Yun WJ, Kim YC, Oh IJ, Kim KS. Methylenetetrahydrofolate reductase C677T polymorphism in patients with lung cancer in a Korean population. BMC Med Genet. 2011; 12:28.

57. Al-Motassem Y, Shomaf M, Said I, Berger S, Ababneh N, Diab O, Obeidat N, Awidi A. Allele and Genotype Frequencies of the Polymorphic Methylenetetrahydrofolate Reductase and Lung Cancer in ther Jordanian Population: a Case Control Study. Asian Pac J Cancer Prev. 2015; $16: 3101-9$.

58. Sun T, Gao Y, Tan W, Ma S, Shi Y, Yao J, Guo Y, Yang M, Zhang X, Zhang Q, Zeng C, Lin D. 2007. A six-nucleotide insertion-deletion polymorphism in the CASP8 promoter is associated with susceptibility to multiple cancers. Nat Genet. 2007; 39:605-613.

59. Ren YW, Yin ZH, Wan Y, Guan P, Wu W, Li XL, Zhou BS. P53 Arg72Pro and MDM2 SNP309 polymorphisms cooperate to increase lung adenocarcinoma risk in Chinese female non-smokers: a case control study. Asian Pac J Cancer Prev. 2013; 14:5415-20.

60. Khoo KH, Verma CS, Lane DP. Drugging the p53 pathway: understanding the route to clinical efficacy. Nat Rev Drug Discov. 2014; 13:217-236.

61. Sarchianaki E, Derdas SP, Ntaoukakis M, Vakonaki E, Lagoudaki ED, Lasithiotaki I, Sarchianaki A, Koutsopoulos A, Symvoulakis ES, Spandidos DA, Antoniou KM, Sourvinos G. Detection and genotype analysis of human papillomavirus in non-small cell lung cancer patients. Tumor Biol. 2014; 35:3203-3209.

62. Jain N, Singh V, Hedau S, Kumar S, Daga MK, Dewan R, Murthy NS, Husain SA, Das BC. Infection of human papillomavirus type 18 and p53 codon 72 polymorphism in lung cancer patients from India. Chest. 2005; 128:3999-4007.

63. Amaral CM, Cetkovská K, Gurgel AP, Cardoso MV, Chagas BS, Paiva Júnior SS, de Lima Rde C, Silva-Neto JC, Silva LA, Muniz MT, Balbino VQ, Freitas AC. MDM2 polymorphism associated with the development of cervical lesions in women infected with Human papillomavirus and using of oral contraceptives. Infect Agent Cancer. 2014; 9:24. 
64. Li T, Lu ZM, Guo M, Wu QJ, Chen KN, Xing HP, Mei Q, Ke Y. p53 codon 72 polymorphism $(\mathrm{C} / \mathrm{G})$ and the risk of human papillomavirus-associated carcinomas in China. Cancer. 2002; 95:2571-2576.

65. Hashemi M, Eskandari-Nasab E, Fazaeli A, Rezaei H, Mashhadi MA, Arbabi F, Taheri M. Bi-directional PCR allele-specific amplification (bi-PASA) for detection of caspase-8 $-6526 \mathrm{~N}$ ins/del promoter polymorphism (rs3834129) in breast cancer. J Gene. 2012; 15:176-9.

66. Horikawa Y, Nadaoka J, Saito M, Kumazawa T, Inoue T, Yuasa T, Tsuchiya N, Nishiyama H, Ogawa O, Habuchi T. Clinical implications of the MDM2 SNP309 and p53 Arg72Pro polymorphisms in transitional cell carcinoma of the bladder. Oncol Rep. 2008; 20:49-55.

67. Liu J, Tang X, Li M, Lu C, Shi J, Zhou L, Yuan Q, Yang M. Functional MDM4 rs4245739 genetic variant, alone and in combination with P53 Arg72Pro polymorphism, contributes to breast cancer susceptibility. Breast Cancer Res Treat. 2013; 140:151-157.

68. Boraldi F, Costa S, Rabacchi C, Ciani M, Vanakker O, Quaglino D. Can APOE and MTHFR polymorphisms have an influence on the severity of cardiovascular manifestations in Italian Pseudoxanthoma elasticum affected patients? Mol Genet Metab Rep. 2014; 1:477-482.

69. Cheng Z, Wang W, Dai LL, Kang Y. MTHFR C667T polymorphism association with lung cancer risk in Henan province: a case-control study. Asian Pac J Cancer Prev. 2012; 13:2491-4.
70. Krawczyk P, Kucharczyk T, Kowalski DM, Powrózek T, Ramlau R, Kalinka-Warzocha E, Winiarczyk K, Knetki-Wróblewska M, Wojas-Krawczyk K, Kałakucka K, Dyszkiewicz W, Krzakowski M, Milanowski J. Polymorphisms in TS, MTHFR and ERCC1 genes as predictive markers in first-line platinum and pemetrexed therapy in NSCLC patients. J Cancer Res Clin Oncol. 2014; 140:2047-57.

71. Kucharczyk T, Krawczyk P, Powrózek T, Kowalski DM, Ramlau R, Kalinka-Warzocha E, Knetki-Wróblewska M, Winiarczyk K, Krzakowski M, Milanowski J. The Effectiveness of Pemetrexed Monotherapy Depending on Polymorphisms in TS and MTHFR Genes as Well as Clinical Factors in Advanced NSCLC Patients. Pathol Oncol Res. 2016; 22:49-56.

72. Smit EF, Burgers SA, Biesma B, Smit HJ, Eppinga P, Dingemans AM, Joerger M, Schellens JH, Vincent A, van Zandwijk N, Groen HJ. Randomized phase II and pharmacogenetic study of pemetrexed compared with pemetrexed plus carboplatin in pretreated patients with advanced non-smallcell lung cancer. J Clin Oncol. 2009; 27:2038-2045.

73. Li X, Shao M, Wang S, Zhao X, Chen H, Qian J, Song X, Wang J, Jin L, Wu J, Li Q, Bai C, Han B, et al. Heterozygote advantage of methylenetetrahydrofolate reductase polymorphisms on clinical outcomes in advanced non-small cell lung cancer (NSCLC) patients treated with platinumbased chemotherapy. Tumour Biol. 2014; 35:11159-70. 